\title{
ECONOMICS
}

\section{CONVERGENCE AND TRANSITIONAL DYNAMICS OF CHINA'S INDUSTRIAL OUTPUT: A COUNTY-LEVEL STUDY USING A NEW FRAMEWORK OF DISTRIBUTION DYNAMICS ANALYSIS}

by

\section{Tsun Se Cheong}

Business School

University of Western Australia

and

Yanrui Wu

Business School

University of Western Australia 


\title{
CONVERGENCE AND TRANSITIONAL DYNAMICS OF CHINA'S INDUSTRIAL OUTPUT: A COUNTY-LEVEL STUDY USING A NEW FRAMEWORK OF DISTRIBUTION DYNAMICS ANALYSIS
}

\author{
Tsun Se Cheong*, Yanrui Wu \\ Business School, University of Western Australia, 35 Stirling Highway, Perth, WA 6009, Australia \\ ${ }^{*}$ Corresponding author. Tel.: +618 64885639 \\ Email addresses: Tsun.Cheong@uwa.edu.au (T. S. Cheong), Yanrui.Wu@uwa.edu.au (Y. Wu).
}

DISCUSSION PAPER 14.21

\begin{abstract}
:
Many scholars have argued that the huge increase in regional inequality in China can be attributed greatly to the disparity in industrialization. This paper contributes to the literature by providing empirical evidence on the transitional dynamics of industrial output by employing a new framework of distribution dynamics analysis, namely the Mobility Probability Plot (MPP), and a database compiled at the county-level. The new framework can address several inadequacies of the traditional display tools in the distribution dynamics literature, while the database is made up of counties and county-level cities in 22 provinces in China. Stochastic kernel analyses are performed for the nation, the economic zones and the provinces individually so as to provide an in-depth understanding of the evolution and convergence of industrial output. This study fills the gap in the literature and provides information on mobility of the county-level units, which can greatly aid the policy making process.
\end{abstract}

Keywords: China; county-level; convergence; distribution dynamics; industrialization JEL codes: O14, O53, R11 


\section{Introduction}

China has experienced dramatic economic growth since the initiation of economic reforms in 1978. Gross domestic product (GDP) of China increased from 365 billion Yuan in 1978 to 51.89 trillion Yuan in 2012, while GDP per capita in China increased from 381 Yuan to 38420 Yuan (State Statistical Bureau, 2013). In that period, GDP per capita increased at an annual real rate of 8.8\%, whilst the annual growth rate of GDP was 9.9\%. The real growth rate of the primary sector in this period was $4.6 \%$ which was dwarfed by the growth rates of the secondary sector $(11.5 \%)$ and the tertiary sector $(10.9 \%)^{1}$. The annual growth rate of GDP is very close to the growth rate of secondary sector in that period, which hints a possible link between the two. It is widely postulated that industrialization has strongly promoted economic growth, for example, Yu (2012) studied industrialization in China and claims that the impressive economic growth can be attributed mainly to the successes in structural transformation and industrial upgrading.

However, regional inequality in China has also increased dramatically in that period. Basically, the increase in inequality can be attributed mainly to the extremely unbalanced industrial development in China. This fact is demonstrated by Cheong and Wu (2014) and Huang, et al. (2003), who show that the disparity in industrial output (value-added) is the largest contributor to regional inequality. Given that an increase in inequality in China can exert adverse impacts on the well-being of the people (Klasen, 2009), the progress of poverty reduction (Fosu, 2009; Rupasingha \& Goetz, 2007; Zhuang, 2008), the economic growth (Alesina \& Perotti, 1996; Alesina \& Rodrik, 1994; Deininger \& Squire, 1998; Huang, et al., 2009; Persson \& Tabellini, 1994), and also the social stability (Cheong \& Wu, 2013a), therefore, it calls for a thorough examination of the disparity, evolution and convergence of industrialization in China. However, most of the studies on inequality in industrial output have been based on provincial level data, and thus the policy implications derived from these studies are valid for formulating policies at the provincial level only. Hence, many scholars argue that it is necessary to include county-level or prefectural level data in research (Akhmat \& Bochun, 2010; Herrmann-Pillath, et al., 2002a, 2002b; Li \& Wei, 2010; Wei, 1999, 2002; Wei \& Fan, 2000; Wei \& Kim, 2002; Wei \& Ye, 2004; Wei \& Ye, 2009; Yu \& Wei, 2007), however, because of the difficulty in data preparation, most of the studies are still confined to the use of provincial level data. Even though a few studies have been conducted using county-level or prefectural level data, they are plagued by the problems of a short time-span (for only a particular year) and limited coverage (only for a few provinces).

\footnotetext{
${ }^{1}$ All the economic activities in China can be categorized into three strata of industries, namely, the primary industry, which refers to agriculture, forestry, animal husbandry and fishery and services in support of these industries; the secondary industry, which refers to mining and quarrying, manufacturing, production and supply of electricity, water and gas, and construction; and the tertiary industry, which refers to all other economic activities not included in the primary or secondary industries (State Statistical Bureau, 2013).
} 
Given that the existing literature cannot provide policy-makers relevant county-level information on industrialization in mitigating regional inequality. Therefore, this study aims to fill the gap in the literature by examining inequality of industrial output through performing county-level transitional dynamics analysis. The database used in this study is made up of counties and county-level cities in 22 provinces, and includes more than 20000 county-level data from 1997 to 2010. To the best of our knowledge, this is the most comprehensive research ever undertaken at the county-level for investigating disparity and convergence of industrial output in China by using distribution analysis. Stochastic kernel analysis is carried out for the nation, the economic zones ${ }^{2}$ and the provinces individually so as to provide an in-depth understanding of the evolution and convergence of industrial output in China. Moreover, this paper also proposes a new analytical framework for interpreting mobility probability which can be used in conjunction with the contour map or three-dimensional plot. The proposed new framework offers additional insights and greatly enhances the traditional distribution dynamics analysis (Quah, 1993a, 1993b, 1996a, 1996b, 1996c, 1997). Besides, by adopting the new framework, this study can provide a comparison of transitional dynamics of the four economic zones. This can thus reveal the effectiveness of regional development campaigns in mitigating regional inequality. Finally, this paper evaluates the possibility of convergence in industrial output for every individual province. The findings foster better understanding of the role of industrialization and provide relevant information for formulation of regional industrial policies in alleviating intra-provincial regional disparity.

The remainder of the article is organized as follows: Section 2 presents the literature review; Section 3 presents the data preparation procedure; Section 4 provides a discussion of the methodology and proposes a new framework of presentation for distribution dynamics analysis; empirical results are presented in Section 5; finally, conclusions and perspectives for future researches are provided in Section 6.

\section{Literature Review}

Kuznets (1955) suggests that industrialization would lead to an increase in inequality in the early stages of economic development. His argument is widely accepted and many researchers suggest that industrialization in China has exacerbated regional inequality (Golley, 2002; Kanbur \& Zhang, 2005; Pradhan, 2009; Rozelle, 1994, 1996; Tsui, 2007; Tsui, 1996; Wei, 1998; Yang, 2002). It is worth noting that in the early stage of economic reforms, the township and village enterprise (TVE) sector played a prominent role in industrialization in rural China and many researchers also find that the unequal development in that sector had led to an increase in regional inequality (Wan, 2004; Yao,

\footnotetext{
2 Before 2006, China was divided into three economic zones, namely, the eastern, central and western zones. The eastern zone is also termed as the 'coastal' region. The 'inland' region (some refer to it as the 'interior' region) is comprised of the central and western zones. However, the Chinese government started to divide China into four economic zones, namely, the eastern, central, western and the newly added north-eastern zones in the Eleventh Five-Year Plan.
} 
1997; Zhang, 1999). These studies all confirm that industrialization in China is positively correlated with inequality.

However, other researchers focus on the study of inequality in industrial output and study its impact on overall regional inequality. Huang, et al. (2003) performed a decomposition of the Gini coefficient by using provincial data from 1991 to 2001, and they find that the inequality in the secondary industry sector is the primary contributor to the inequality in total regional economic development. This finding is supported by that of Cheong and Wu (2014), who show that the inequality in the secondary industry sector is the principal contributor to regional inequality at all the spatial levels (namely, the provincial, economic zonal, inland-and-coastal, and national levels) during the period from 1997 to 2010. The authors even show that national inequality in China can be lowered by half if industrialization were distributed evenly.

Although the importance of understanding the inequality in industrial output is well established, no research has been conducted to study the distribution dynamics of industrial output at the county-level. In fact, many researchers have employed distribution dynamics approach in studying convergence and evolution of different economic characteristics in China (He \& Zhang, 2007; He, 2010; Herrerías, 2012; Herrerías, et al., 2010; Herzfeld, 2008; Ho \& Li, 2006, 2010; Li, 2003; Liao \& Wei, 2012; Liu \& Zou, 2011; Pu, et al., 2005; Sakamoto \& Fan, 2010, 2013; Sakamoto \& Islam, 2008; Villaverde \& Maza, 2012; Villaverde, et al., 2010; Wang, 2011; Wang \& Zhu, 2013; Wei \& Ye, 2009; Zhou \& Zou, 2010; Zhu, et al., 2008). However, most of these researchers have focused on the inequality in per capita income or GDP, though some of them have employed distribution dynamics analysis in studying the inequality in other socioeconomic issues. For example, Zhu, et al. (2008), Wang (2011) and Herrerías (2012) examine the convergence of productivity, while Wang and Zhu (2013) use distribution dynamics approach to investigate city-size distribution which is measured by urban or nonagricultural population in each city. Sakamoto and Fan (2013) even use it to study the evolution of four value-added components, namely the compensation of employees, operating surplus, depreciation of fixed assets, and net tax on production.

Another noteworthy feature of this strain of research is that most of these studies are based on provincial data, though there are a few exceptions, for example, Sakamoto and Fan (2010) examine the transitional dynamics of 75 cities and counties in the Yangtze River delta. In fact, the coverage in all the present county-level distribution dynamics studies is either limited to the county-level units within a few provinces of the eastern economic zone (Liao \& Wei, 2012; Wei \& Ye, 2009) or only cities, without considering counties (Ho \& Li, 2010; Wang \& Zhu, 2013; Zhou \& Zou, 2010). It should be noted that none of these distribution dynamics studies is based on industrial output. Regrettably, because of the unavailability of literature, distribution dynamics of industrial output at the county-level remains virtually unknown to the academic communities. Thus, the aim of this paper is to study the evolution and convergence of industrial output in China by using a county-level database which is compiled from 22 provinces situated in all the economic zones. 


\section{Data}

The municipality of Chongqing was separated from Sichuan in 1997 and since then the data of Chongqing and Sichuan have been made available individually. Therefore, 1997 is selected as the beginning year of the database. The data used in this study are population and gross regional product (GRP) in the secondary industry sector of the counties and county-level cities from 1997 to 2010. The county-level database was compiled from the Provincial Statistical Yearbook of each province (State Statistical Bureau, 1998 - 2011a). More than 300 Provincial Statistical Yearbooks were used in the first stage of data compilation. But because of inconsistency and incompleteness of the county-level data, the China Statistical Yearbook for Regional Economy (State Statistical Bureau, 2004 - 2008) was then used for data checking and verification. However, if an inconsistency was found between the data of the Provincial Statistical Yearbook of each province and those from the China Statistical Yearbook for Regional Economy, then the Provincial Yearbook for each province (State Statistical Bureau, 1998 - 2011b) was checked to determine which data is correct. More than 100 Provincial Yearbooks were used in that checking process. In sum, more than 400 yearbooks were employed in the data preparation process. Optical recognition techniques and spreadsheet programming were then used to transform voluminous amount of data in the printed publications into electronic data. To the best of our knowledge, this is the most complete database ever constructed for the investigation of distribution dynamics of GRP at the county-level.

It is worth noting that the county-level units in China can be categorized into districts, counties and county-level units. Unfortunately, individual data of each district is not available for many provinces, especially, in the beginning of our study period, so districts are not included in the analysis. Accordingly, the municipalities of Beijing, Tianjin, Shanghai and Chongqing are not included because most of the county-level units within these municipalities are districts. The provinces included in this study are:

a) Eastern zone: Hebei, Jiangsu, Zhejiang, Fujian, Guangdong and Hainan. The municipalities of Beijing, Tianjin and Shanghai are excluded in this study. The province of Shandong is not included because of unavailability of data.

b) Central zone: Anhui, Jiangxi, Henan, and Hunan. The provinces of Shanxi and Hubei are not included because of unavailability of data.

c) Western zone: Inner Mongolia, Guangxi, Sichuan, Guizhou, Yunnan, Gansu, Qinghai, Ningxia and Xinjiang. The municipality of Chongqing is excluded in this study. The provinces of Shaanxi and Tibet are not included because of unavailability of data.

d) North-eastern zone: Liaoning, Jilin and Heilongjiang.

Relative secondary industry GRP per capita (SGRPPC) can be computed by the GRP in the secondary industry sector of a county-level unit divided by its population and the regional mean. This value is then deflated by the provincial secondary industry deflator so as to convert the value 
to 1997 constant prices. Because deflator index for each individual county-level unit is not available, so provincial deflator was used in the process. However, there is one thorny issue in the compilation of this database, namely the change in administrative divisions at the county-level. From time to time, the government will introduce boundary changes to the county-level units, which can distort the distribution dynamics analysis. For example, the transfer of the ownership of a high output town from a high output county to a low output county will result in a sudden decline in disparity. Therefore, the data needed to be adjusted accordingly to ensure that the data are all comparable across time. The website of Administrative Divisions in China (http://www.xzqh.org) is used to identify boundary change for every county-level unit from 1997 to 2010 . Whenever there is a boundary change which involves two county-level units, then these units were aggregated. This approach is first suggested by Fan (1995), however, since district is not included in the database, any boundary change which involves a county-level unit and a district will result in the deletion of this data, though this kind of administrative change is infrequent in the study period. The data are comparable across time after adjustment and so the analysis can thus reveal the distribution dynamics better.

\section{A New Analytical Framework}

There are many different approaches used in convergence analysis. Some of the previous studies are based on time series techniques such as cointegration tests and unit root tests (Bernard \& Durlauf, 1995, 1996; Hobijn \& Franses, 2000; Lim \& McAleer, 2004; Oxley \& Greasley, 1995; Pesaran, 2007). Some follow the concepts of $\sigma$-convergence and $\beta$-convergence (Barro \& Sala-I-Martin, 1991, 1992), while others employ the distribution dynamics approach. Although $\beta$-convergence is frequently employed in the study of convergence, this method is subjected to many criticisms. By drawing an analogy of the cross-section regression tests of the convergence hypothesis with those of the classical Galton's fallacy, Quah (1993b) shows that these cross-section tests are misleading. Li (2003) also shows that, even if the coefficient on the initial level of income is negative, however, it is perfectly consistent with the absence of convergence. The fact of the coefficient being negative is a necessary but not sufficient condition for convergence. Cheshire and Magrini (2000) claim that the $\beta$-convergence approach is a poor test of the hypothesis in neoclassical growth models, while Quah (1993a) suggests that both $\sigma$ - and $\beta$-convergence cannot show the dynamic changes clearly. In fact, the studies of $\sigma$ - and $\beta$-convergence can only provide a summary of statistics for the evolution of distribution but not the details of mobility, and hence identical summary statistics can be derived from two distributions with entirely different mobility. For that reason, distribution dynamics approach is gaining popularity because it has a number of advantages over the other approaches. Distribution dynamics analysis takes transitional dynamics into consideration and can show the mobility probability of the county-level units. Moreover, it can also provide a forecast of future distribution based on historical data. 
The distribution dynamics approach can be further divided into the traditional Markov transition matrix analysis and the stochastic kernel approach. However, one controversial issue of the Markov transition matrix approach is the demarcation of states because the selection of grid value in that process is somewhat arbitrary. The stochastic kernel approach can circumvent the problem of demarcation as it can be viewed as an extension of the traditional Markov transition matrix approach with a continuous infinity of states.

The first step of the stochastic kernel approach is the construction of a kernel density function. This function is then combined with transition data so as to compute the transition probability kernel function. Finally, the ergodic density function, which shows the long-run steady state, can be worked out.

The kernel estimator is defined as follows:

$\hat{f}(x)=\frac{1}{n h} \sum_{i=1}^{n} K\left(\frac{x-X_{i}}{h}\right)$

where $K$ is the Epanechnikov kernel function, $h$ is the bandwidth, $n$ is the number of observations, and $X_{i}$ is an observed value of relative SGRPPC. The bandwidth is chosen optimally according to the procedures proposed by Silverman (1986). It should be noted that Quah (2001) suggests using annual transitions in convergence analysis because in that way, the sample size can be larger and thus the estimation results would be more reliable. Therefore, the analysis in next section is based on the data of annual transition of relative SGRPPC of all the county-level units.

However, the estimation of the stochastic kernel density can be seriously affected if the distribution has a long tail because under-smoothing may appear in areas with only a few observations, while over-smoothing may occur in areas with many observations. This is a critical issue because the distributions of many socioeconomic indicators tend to have a long tail. In order to solve this problem, kernels of variable bandwidth should be used to take sparseness of data into consideration. Therefore, the adaptive kernel method with flexible bandwidth is employed in this research. This method involves two steps: first, a pilot estimate is computed to determine the density, and then the bandwidth is rescaled by a factor that reflects the density at that point (for details, see Silverman, 1986).

Suppose that the evolution of the distribution is first order, time invariant, and further assume that the distribution at time $t+\tau$ depends on $t$ only and not on any previous distribution, then the relationship between the distributions of relative SGRPPC at time $t$ and time $t+\tau$ can be represented as:

$f_{t+\tau}(z)=\int_{0}^{\infty} g_{\tau}(z \mid x) f_{t}(x) d x$

where $f_{t}(x)$ is the density function of the distribution of relative SGRPPC at time $t$, and $g_{\tau}(z \mid x)$ is the transition probability kernel which maps the distribution from time $t$ to $t+\tau$, and $f_{t+\tau}(z)$ is 
the $\tau$-period-ahead density function of $z$ conditional on $x$. (see Johnson, 2000; Johnson, 2005; and Juessen, 2009 for details).

The ergodic density is the long-run steady state which will emerge when $\tau$ is infinite. Based on formula (2), the ergodic density function, given that it exists, can be found by:

$f_{\infty}(z)=\int_{0}^{\infty} g_{\tau}(z \mid x) f_{\infty}(x) d x$

where $f_{\infty}(z)$ is the ergodic density function.

For the stochastic kernel approach, the probability values of the transitions are not available for further examination; therefore, estimation result is usually presented in contour map form or three-dimensional plot. Both of them show the conditional density of the county-level unit's probability of transition (displayed by its height with the notion that the greater the height, the higher the probability) from a particular value of relative SGRPPC towards other values after transition. It should be noted that because the values used in the analysis are all measured relative to the mean, therefore, if a county-level unit has a relative SGRPPC value larger than one, it implies that this county-level unit's SGRPPC is higher than the average, while if the relative SGRPPC value is smaller than one, then that county-level unit's SGRPPC is lower than the average. Given that the diagonal line of the contour map and three-dimensional plot lies on the same values of relative SGRPPC before transition and after transition, it follows that if most of the probability mass lies above the diagonal for a particular value of relative SGRPPC, then those county-level units should have a higher probability of moving up in the distribution. On the contrary, if most of the probability mass lies below the diagonal, then these county-level units should have a higher probability of moving down. Therefore, generally speaking, convergence to the mean SGRPPC is more likely to happen when a large portion of the probability mass of the below-average SGRPPC county-level units (those relative SGRPPC smaller than one) lies above the diagonal, and a major portion of the probability mass of the above-average SGRPPC county-level units (those relative SGRPPC greater than one) lies below the diagonal. In that way, the above-average county-level units will tend to move downward in the distribution, whereas the below-average ones will tend to move upward, thereby making convergence to the mean SGRPPC possible.

However, sometimes it is very difficult to determine where most of the probability mass lies by observing the contour map and the three-dimensional plot by eye. Therefore, Hyndman (1996) and Hyndman, et al. (1996) put forward a new density estimator and two visualization tools, namely the stacked conditional density plots and the highest density region (HDR) plots, in an attempt to make interpretation easier. Although the use of HDR plot alleviates the problem of visualization to some extent, it cannot improve interpretation under a number of circumstances. For example, if there are two peaks in the conditional density strip and if the highest one lies on one side of the diagonal whereas another slightly lower peak lies on the other side of the diagonal. Another case is when the density is somewhat constant for a long range of data in the conditional density strip. In these 
examples, it is very hard to interpret where the largest portion of the probability mass lies even if the HDR plot is employed.

Besides, all the general display tools of the stochastic kernel approach, namely the contour map, the three-dimensional plot, the HDR plot and the stacked conditional density plot, cannot present comparison results clearly in a combined figure. Basically, if one would like to compare the transitional dynamics of two or more periods, it is always useful to superimpose the plots of different periods into one figure so as to make comparison easier. However, the three-dimensional nature of the stacked conditional density plot and the three-dimensional plot just do not allow superimposing because the one situated at the front will always block the view of the one situated at the back. Similarly, superimposing HDR plots for different periods within one figure is infeasible as the one on top will always hide the one underneath from view. Therefore, contour map (which is made up of lines) is the only possible candidate for superimposing. However, even so, it is impossible to present two contour maps in one figure clearly because the combined figure will have too many contour lines after superimposing, which makes comparison very difficult. One may argue that by reducing the number of contour lines in each map, it is possible to combine several maps into one figure; however, it means that some data points have to be deleted. Basically, the use of this approach cannot be done without loss of information, and still, it cannot be applied when one wants to superimpose a large number of contour maps at the same time.

Yet another improvement is suggested by Foster and Rothbaum (2012). They propose the use of mobility curve which is based on a population-weighted measure of mobility across cutoff values. However, it is difficult to observe the mobility of those entities which are few in number, especially for the entities located at the far end of the distribution. This problem is more pronounced for China as the distribution of the relative SGRPPC usually has a very long right tail with only a few entities at the far end.

We thereby propose a new framework for analyzing transitional dynamics. Basically, it is an extension of the approach adopted by Cheong (2012) and Cheong and Wu (2012, 2013b) who calculated the net probabilities of moving upward in the distribution for different states while they performed the traditional Markov transition matrix analyses. The net probability of moving up is based on the difference between the sum of probability values of moving up and the sum of probability values of moving down for each state in the transition matrix. Therefore, for the stochastic kernel approach, the sum of upward mobility probabilities, $p_{u}(x)$, at $x$ can be calculated as:

$p_{u}(x)=\int_{x}^{\infty} g_{\tau}(z \mid x) d z$

It is worth noting that $p_{u}(x)$ is also the sum of probabilities above the diagonal for a particular value of $x$. The sum of downward mobility probabilities, $p_{d}(x)$, can be computed as: 
$p_{d}(x)=\int_{0}^{x} g_{\tau}(z \mid x) d z$

Similarly, $p_{d}(x)$ is the sum of probabilities below the diagonal for a particular value of $x$. Therefore net upward mobility probability, $p(x)$, at $x$ is:

$p(x)=p_{u}(x)-p_{d}(x)$

The mobility probability plot (MPP) is thus defined as

$p(x)=\int_{x}^{\infty} g_{\tau}(z \mid x) d z-\int_{0}^{x} g_{\tau}(z \mid x) d z$

The MPP plots the net upward mobility probability against relative SGRPPC. It is expressed in percentage (\%). The value of net upward mobility probability ranges from -100 to 100. A positive value means that the units have a net probability of moving upward, while a negative value means that the units have a net probability of moving downward. The MPP can thus show the distribution of the probability mass. A value larger than zero means most of the probability mass lies above the diagonal, while a value smaller than zero means most of the probability mass lies under the diagonal.

This new framework has many advantages over the common display tools. First, it can provide a more direct and better visual representation of the net upward mobility. Second, it can offer precise information on the distribution of the probability mass. As mentioned earlier, the traditional display tools cannot pinpoint clearly where the largest portion of the probability mass locate, while MPP can indicate whether most of the probability mass lies above the diagonal or not. Third, since the MPP is a curve, thus many MPPs can be superimposed together in the same figure. This can make the comparison of transitional dynamics in different periods much easier. Fourth, mobility probability of a particular group of county-level units can be identified by examining the MPP. The new framework can pinpoint which group has a higher probability of moving up and which group has a higher probability of moving down, therefore, it can provide critical information for developing long-term policy for the county-level units. In summary, MPP is a very powerful tool in presenting distribution dynamics analysis results. Not only it can offer valuable information, which is not directly visible from the traditional contour map and the three-dimensional plot, but it can also greatly improve visual presentation, thereby facilitating interpretation of the transitional dynamics. The new framework is employed with other display tools in the following section which serves as an illustration of how the MPP can be applied in distribution dynamics analysis.

\section{Results and Discussions}

The transitional dynamics of the county-level units across 1997-2010 is shown in Figure 1 as three-dimensional plot and Figure 2 as contour map. The contour map is basically an overhead view 
of the three-dimensional plot. These two types of display tools are the most common in the stochastic kernel analysis literature. According to Figure 1, the width of the transition probability kernel is very narrow and the density mass is concentrated along the 45-degree diagonal line, implying considerable persistence in the relative SGRPPC distribution. This fact can be observed more clearly in Figure 2, which shows the contour map of the stochastic transition probability kernel of relative SGRPPC across the range 0 to 2 . It should be noted that the convergence process will be very slow when there is a high concentration of probability mass along the diagonal, while faster rates of convergence can be achieved if most of the probability mass is concentrated parallel to the axis of relative SGRPPC before transition (that is the horizontal axis which is labelled as $t$ ). It is thus apparent from Figure 1 and Figure 2 that convergence in China is a slow process and it will take a long time to achieve.

In order to gain an understanding of the transitional dynamics, one can examine the distribution of the probability mass in the three-dimensional plot and the contour map. Since the SGRPPC values are calculated relative to the regional mean (the value of the mean is one), therefore if most of the probability mass lies above the diagonal in the below-average portion (that is the portion with range 0 to 1 ), while most of the probability mass lies below the diagonal for the above-average portion (that is the portion with values greater than one), then it can be expected that the probability of convergence to the mean SGRPPC is high. However, because the persistence is so strong and since most of the probability mass is concentrated along the diagonal, therefore, it is very hard to determine where the greatest portion of the probability mass lies by observing Figure 1 and Figure 2 by eye. The new framework of MPP can tackle this problem effectively and offer a direct interpretation of the probability mass. The MPP of all the county-level units across 1997 to 2010 is shown in Figure 3. It can be observed that the MPP curve is below zero for the range 1 to 5 implying that the above-average county-level units have a net probability of moving down in the distribution, though they are more likely to remain in roughly the same SGRPPC level because of the high persistence. However, the MPP shows that the units in the range from 0.2 to 1 also have a net probability of moving down and only those units under 0.2 have a net probability of moving up. Therefore, it means that most of the county-level units in China with a relative SGRPPC value above 0.2 would tend to register a decline in their relative SGRPPC, while the units with relative SGRPPC values below 0.2 would likely to register an increase. Therefore, when the policy makers formulate long-term industrial development policy for rural China, they could focus mainly on those counties and county-level cities with a relative SGRPPC value in the range 0.2 to 1 since these below-average units are extremely susceptible to a further decline in their relative SGRPPC. MPP can pinpoint precisely the group of county-level units which need special attention and it can thus help the policy makers in formulating a priority list for the county-level units.

In fact, MPP not only can indicate the exact value of relative SGRPPC, but the information derived from MPP can also reveal important information on the ergodic distribution. Figure 4 shows that a uni-modal relative SGRPPC distribution can be achieved in the long run. However, the entities will 
converge to a value around 0.2 in relative SGRPPC, which is far below the mean. This signifies that even though convergence is possible, many entities will congregate around the lower part of the distribution. It can be observed that the ergodic distribution basically impart the same information on transitional dynamics as offered by the MPP. As mentioned earlier, the MPP shows that the units with relative SGRPPC values lower than 0.2 tend to move upward in the distribution, while the ones with relative SGRPPC values greater than 0.2 tend to move down, therefore, a lot of the county-level units will migrate and congregate around 0.2 in the long run as indicated by the peak of the ergodic distribution.

It is of interest to examine the transitional dynamics in different periods so as to provide an understanding of the impacts of time on the evolution of distribution dynamics. Three datasets are constructed for that purpose; they are based on the transitions in three periods, namely 1997-2000, 2000-2005 and 2005-2010. The first dataset has three transition episodes (that is 1997 to 1998, 1998 to 1999 , and 1999 to 2000), whilst each of the other datasets has five transition episodes. Stochastic kernel analyses are performed for each of these datasets individually so as to compute the transitional dynamics of each period. The comparison can be made much easier if it is possible to superimpose the contour maps or the three-dimensional plots of the different periods together in one figure, however, as mentioned in previous section, it is infeasible to do that. Therefore, MPP is used and Figure 5 shows the MPPs of the three periods. It can be observed that for most of the time, the MPP of the period 1997-2000 is above zero for the entities with relative SGRPPC values from 0 to 3.7 implying that in the first period, many county-level units had a net probability of moving upward in the distribution and thus an increase in their relative SGRPPC. In the second period (2000-2005), the MPP shows that the units with relative SGRPPC from 0 to 0.2 had a net probability of moving up in the distribution, while the units with relative SGRPPC values greater than 0.2 had a net probability of moving down. The second period signifies a time that many of the county-level units registered a decline in relative SGRPPC, with the exception of those county-level units which had a very low level of industrial output. The MPP of the last period (2005-2010) shows that the entities with relative SGRPPC values lower than 0.5 had a net probability of moving upward in the distribution, while those with relative SGRPPC values higher than 0.5 had a tendency to move down. It seems that there was a great improvement at the lower end as the units with relative SGRPPC values from 0.2 to 0.5 also had a net probability of moving upward as compared with the second period. Moreover, the net probability of moving down also declined significantly for those units with relative SGRPPC values from 0.5 to 1 . Therefore, the third period exhibited a higher tendency of convergence to the mean than the second period.

It should be noted that the biased regional development policy in China has attracted heavy criticism (Cheng \& Zhang, 1998; Fan, 1997; Tang \& Lu, 1996; Zhao \& Gu, 1995). The central government has recognized this problem and initiated several campaigns in an attempt to reduce the gap between the inland and coastal regions. In 1999, the 'Campaign to Open up the West' was launched to stimulate economic development in the western provinces (and Golley, 2007; for details 
of the campaign and its impacts, see Goodman, 2004). The State Council of China issued the document On Implementing the Strategy of Revitalizing the Northeast Old Industrial Base and Other Areas in 2003, which marked the commencement of the 'Revitalize Northeast China' campaign targeting the north-eastern provinces (Zhang, 2008). Finally, the 'Rise of Central China' campaign was initiated in 2004 to target the central provinces (Lai, 2007). These campaigns were launched to foster development in the western, north-eastern and central economic zones so as to reduce the disparity between them and the eastern zone. It is thus of interest to examine the transitional dynamics of different economic zones so as to provide an understanding of the impacts of these campaigns on distribution dynamics of the county-level units. The whole dataset is divided into four datasets, namely the eastern, central, western and north-eastern economic zonal datasets. Stochastic kernel analyses are then performed for each of these datasets individually.

MPPs and the ergodic distributions of the four economic zones are shown in Figure 6 and Figure 7 respectively. It can be observed from Figure 6 that all the MPPs intersect the horizontal axis with values of relative SGRPPC smaller than 1 . The MPPs of the eastern, central and the north-eastern zones cross the horizontal axis in the range of 0.4-0.5, whilst the MPP of the western zone intersects the horizontal axis at around 0.1. The MPP of the eastern zone intersects the axis around 0.5 which is the highest amongst the four economic zones; it implies that the government in the eastern zone had done a much better job than the other zones in promoting industrial growth for the low industrialized regions with relative SGRPPC values lower than 0.5. Figure 6 also indicates that it is very difficult for the units of the western zone to move upward in the distribution. It can be observed that except the units with very low relative SGRPPC (that is below the value of 0.1), many of the units in the western zone tended to register a decline in the relative SGRPPC. Furthermore, for all the values of relative SGRPPC greater than 0.2, the MPP of the western zone stays below the horizontal axis and its net upward probability remains within the range from $-20 \%$ to $-40 \%$. The high net downward mobility probability of the units of the western zone suggests that many of the units in that zone would move downward in the distribution and congregate around the value of 0.1 , therefore, it can be expected that a very significant peak should lie somewhere around the value of 0.1 in the ergodic distribution of the western zone. This fact can be confirmed by Panel (c) of Figure 7. In contrast, the MPP of the north-eastern zone stays a little bit above the horizontal axis for the values of relative SGRPPC in the range 0.6-1.5. Hence, it can be expected that the ergodic distribution of the north-eastern economic zone should be more dispersed than the western zone, while the peak of the north-eastern zone's ergodic distribution should not be as apparent as the one of the western zone. Actually, the shapes of the ergodic distributions and the locations of the peaks, which can be observed from Figure 7, are all in line with the expectations drawn from the interpretation of MPP. The ergodic distribution of the western zone as shown in Panel (c) of Figure 7 has a height of 0.170 which is much higher than the other zones implying the peak of the western zone is more pronounced than the others. In contrast, Panel (d) shows the height of the peak of the north-eastern zone is only 0.012 and the distribution is more dispersed. 
It can be observed that the peaks of the ergodic distributions in Figure 7 lie roughly at the same relative SGRPPC values as where the MPPs and the horizontal axis intersect in Figure 6. All the peaks of the ergodic distribution are situated far under the mean, though the peak of the eastern zone's ergodic distribution is closer to the mean than the other zones. However, since none of the peaks of the four ergodic distributions lie around the value of one, which is the value of the mean, therefore, it implies that convergence to the mean SGRPPC is impossible for all the economic zones.

Figure 8 shows the MPPs of the economic zones in different periods. The changes in transitional dynamics of the eastern and central zones are very similar to those occurred at the national level. Compared the first and the second periods, most of the units in these two zones had a higher upward mobility probability in the first period than the second period. Moreover, many of the county-level units had net downward mobility probability in the second period; however, things had improved in the third period. In contrast, the western and the north-eastern zones present a very different evolution pattern of distribution dynamics as it can be observed that in the second period, the MPPs of these two zones moved upward rather than moved downward. In the third period, the MPP of the western zone dropped considerably implying that many of the county-level units would register a decline in their relative SGRPPC. The effect was widespread and it affected all the units with relative SGRPPC values larger than 0.2. Yet the impact on the north-eastern zone is a little blurred as the MPP dropped in the range from 0-0.8 but rose in the range 0.8-1.4. However, it can be concluded that the government in the north-eastern zone had done a good job in promoting industrial development for the below-average units as the MPPs of the north-eastern zone lie above the horizontal line for most of the values in all the periods.

In order to give a more in-depth analysis of the transitional dynamics, the whole dataset is divided into 22 provincial datasets for further investigation. However, with the aim of facilitating the comparison of provinces within an economic zone, the average used in the provincial analysis is based on the mean of the economic zone in which the province is situated. Figure 9 shows the MPPs of the provinces within the four economic zones. All the MPPs lie above the horizontal axis when the relative SGRPPC is zero, which is a good sign as it means the units with the lowest relative SGRPPC would have a very high tendency to move upward. However, most of the MPPs cross the horizontal axis with relative SGRPPC values smaller than one, implying that many below-average units had difficulty in moving up to the mean. It can also be observed that the provinces exhibit different characteristics in transitional dynamics. However, in order to save space, our discussions are limited to a few selected provinces which have special features in transitional dynamics, though readers are encouraged to study the MPPs of those provinces that they are interested in.

In fact, a great deal of important information can be obtained from observing the movement of MPP. For example, Panel (a) of Figure 9 shows that the MPP of Hainan lies above the horizontal axis in the range of $0-0.12$, but then it moves under the axis from 0.12 to 0.25 and reaches a minimum 
around 0.17. After that, the MPP rises and reaches the maximum at 0.49. Actually, it remains above the horizontal axis till 0.60, however, the MPP stays under the horizontal axis after 0.60 and reaches a minimum at around 1.24. The information gathered from the MPP is valuable for formulating county-level policies in industrial development. For instance, the MPP shows that there is a maximum at 0.49 , so it means those county-level units, with a relative SGRPPC roughly equal to 0.49 , perform quite well as they enjoy high net upward mobility probability. However, attention should be paid to those county-level units with values of relative SGRPPC in the range 0.12-0.25, for which the MPP lies below the horizontal axis, implying that these low industrialized units tend to drop further downward in the distribution. Another concern for Hainan is the MPP reaches -100 around the region of 1.24. This means that the county-level units in Hainan just could not transit through the threshold of 1.24. As a matter of fact, whenever the relative SGRPPC value of a county-level unit reached this level, then it would have a decline in relative SGRPPC which would bring it downward in the distribution. It implies that there might be a development trap in Hainan and therefore, policy makers should take this information into consideration and focus specifically on the units with values of relative SGRPPC greater than 0.6.

It can be observed that the shapes of the MPPs of the provinces are very different even if the provinces are situated in the same economic zone, however, Panel (b) of Figure 9 shows that the shapes of the MPPs of the provinces within the central zone are quite similar to each other implying that the county-level units of the central zone had comparable transitional dynamics. Panel (c) shows that several provinces within the western zone require special attention, for example, the MPPs of the provinces of Guizhou and Gansu lie below the horizontal axis for all the values of relative SGRPPC greater than 0.14 . It means that many of the units in these provinces would register a decline in their relative SGRPPC. Ningxia is another province which deserves attention. The MPP of Ningxia lies below the horizontal axis from 0.25 to 1.24, while it lies above the axis with relative SGRPPC values greater than 1.24. It means that the low output units would tend to move downward in the distribution, while the high output units would tend to move further upward, thereby implying convergence to the mean is very difficult for that province. In contrast, the transitional dynamics of the Jilin province facilitated convergence greatly as can be observed from Panel (d). The MPP of Jilin lies above the horizontal axis from 0 to 1, and then lies below the horizontal axis with values greater than one (though a small part is above the axis around 1.4). It means the below-average units would tend to move upward in the distribution, whereas the above-average units would tend to move downward, therefore one can expect convergence to the mean can be achieved in the long run. This fact can be demonstrated by Panel (u) of Figure 10 which shows the ergodic distribution of the Jilin province. It can be observed that the peak of the ergodic distribution situates around one which is the mean, therefore, the shape of the ergodic distribution is in line with expectations derived from the MPP.

Indeed, Jilin is one of the exceptions to the general pattern. Referring to Figure 10, the peaks of most of the provinces' ergodic distributions situate far below the mean, with only three exceptions, 
namely, Guangxi, Jilin and Liaoning. It means that convergence to the mean is unattainable in many provinces. Another fact which can be observed from Figure 10 is that most of the ergodic distributions have only one peak (uni-modal), however, Hainan, Liaoning, and Zhejiang have two peaks in the ergodic distribution (bi-modal). In fact, the shapes of the ergodic distributions of Inner Mongolia, Hunan, and Yunnan are also bi-modal, though their smaller peaks are not evident. It should be noted that Guangxi has a multi-modal ergodic distribution with three peaks. These findings suggest that convergence clubs have existed in many provinces.

\section{Conclusions}

The results in previous section show that the county-level units in each province have their own specific characteristics. As a matter of fact, the transitional dynamics of the county-level units in one province is completely different from those in another province even if the two provinces are situated in the same economic zone. Therefore, it is improper to develop county-level policy by relying on the findings derived from the provincial level data. However, due to the difficulty in data preparation, most of the studies are still based on data compiled at the provincial level. The aim of this paper is to examine the transitional dynamics of the county-level units' industrial output by using a new framework of distribution dynamics analysis, namely the Mobility Probability Plot (MPP). This study fills the gap in the literature and provides valuable information on mobility of the county-level units, which can greatly aid the policy making process.

The new framework can address several inadequacies of the traditional display tools in the distribution dynamics literature. It can also greatly improve visual presentation and facilitate interpretation. For example, it can provide precise information on the distribution of the probability mass and offer a better visual representation of the net upward mobility. The new framework can also indicate the probability of movement for each entity. Moreover, many MPPs can be superimposed together in the same figure, which can make comparison much easier. In fact, the MPP can be incorporated into the traditional distribution dynamics approach easily and enhance the analysis greatly.

In this study, stochastic kernel analyses are performed for the nation, the economic zones and the provinces individually so as to provide an in-depth understanding of the evolution of county-level industrial output. Based on the ergodic distributions computed in previous section, it is found that convergence to the mean is impossible for most of the groupings, with the exception of a few provinces. However, Huang, et al. (2003) and Cheong and Wu (2014) find that overall regional inequality in China can be attributed largely to the inequality in industrial output, while this study points out that convergence of industrial output to the mean is impossible for most of the groupings, therefore, it implies that regional inequality in China will be exacerbated further and China will continue to be plagued by this problem in the years ahead. 
Actually, firms tend to agglomerate because of the benefits derived from increasing returns to scale, transport costs, knowledge spillovers and the pooling of specialized skills (Marshall, 1920; Redding, 2010). Agglomeration is also subject to the forces of marketization and globalization (He, et al., 2008). Given that there are many virtues of agglomeration, therefore, the next task is to evaluate the benefits and costs of industrial agglomeration so as to determine whether it is worthwhile to have government intervention. If the benefits of industrial agglomeration outweigh the costs, then the government should not impose constraints on agglomeration but should counteract the effect of industrial agglomeration by formulating policy to boost primary and tertiary outputs in the underdeveloped regions. It is hoped that, in this way, regional inequality can be alleviated without affecting industrial development. 


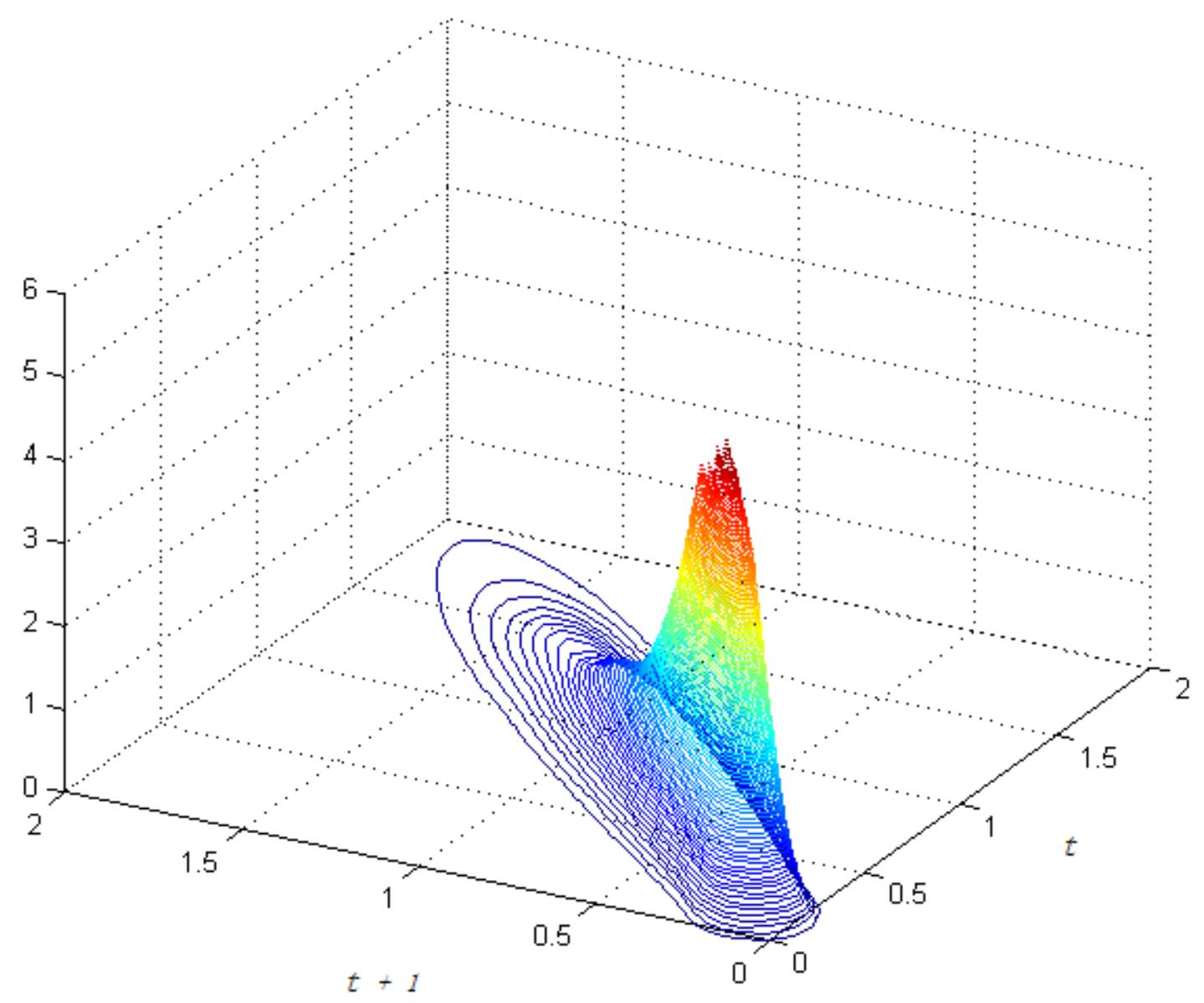

Figure 1 Three-dimensional plot of transition probability kernel for relative SGRPPC of all counties and county-level cities with annual transitions, 1997-2010

Source: Authors’ calculation. 


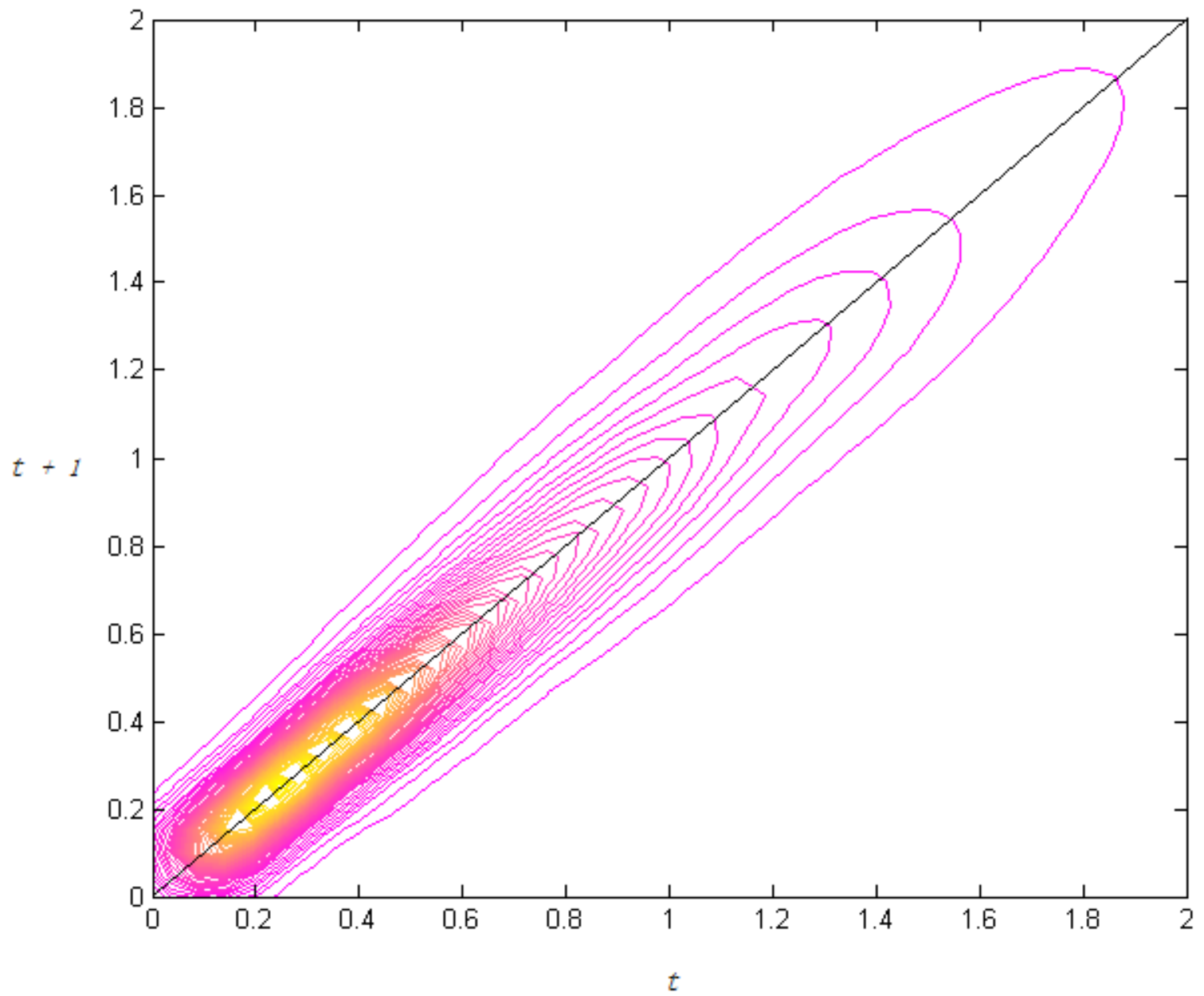

Figure 2 Contour map of transition probability kernel for relative SGRPPC of all counties and county-level cities with annual transitions, 1997-2010

Source: Authors’ calculation. 


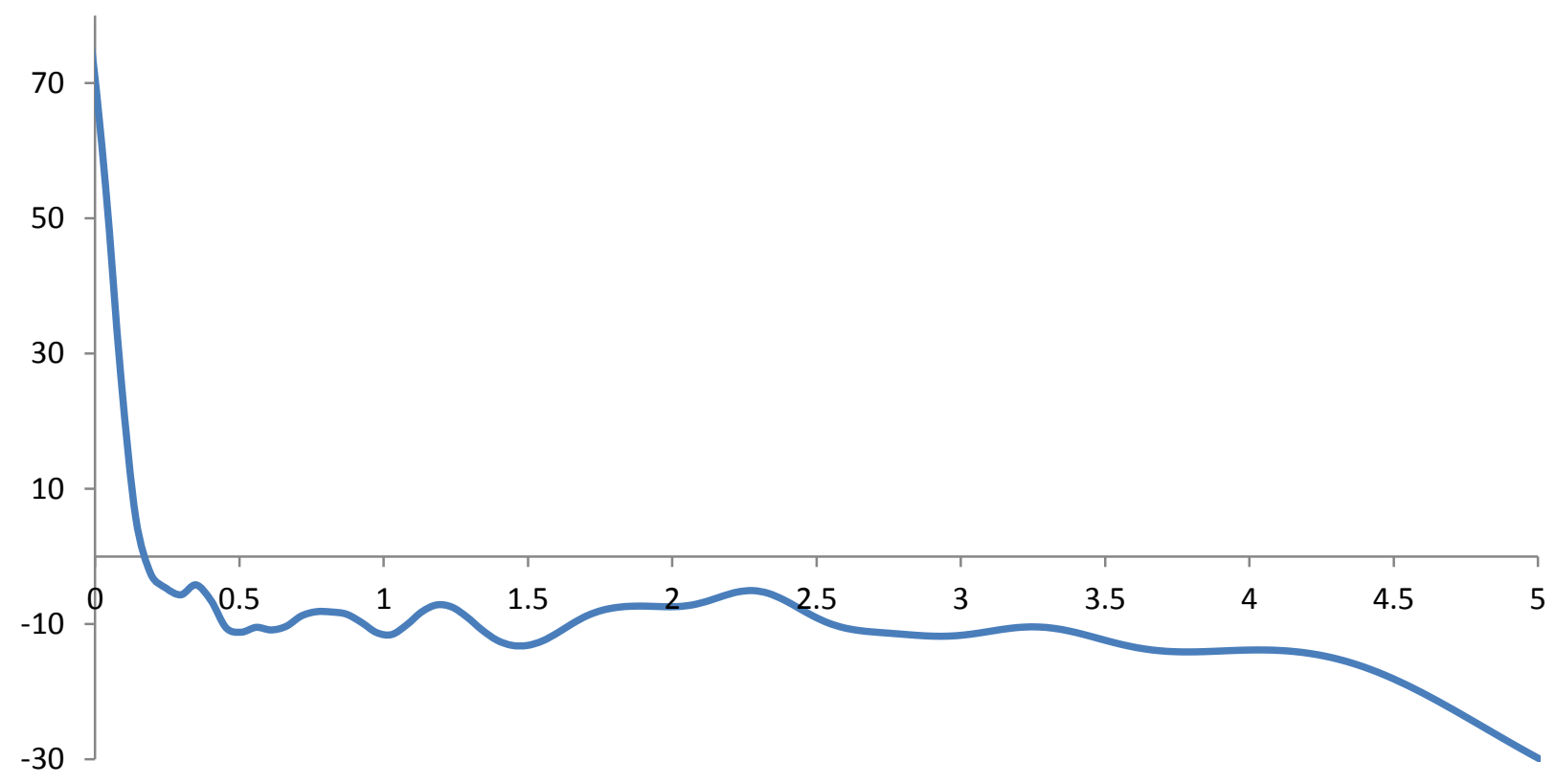

Figure 3 Mobility Probability Plot (MPP) for relative SGRPPC of all counties and county-level cities with annual transitions, 1997-2010

Source: Authors’ calculation.

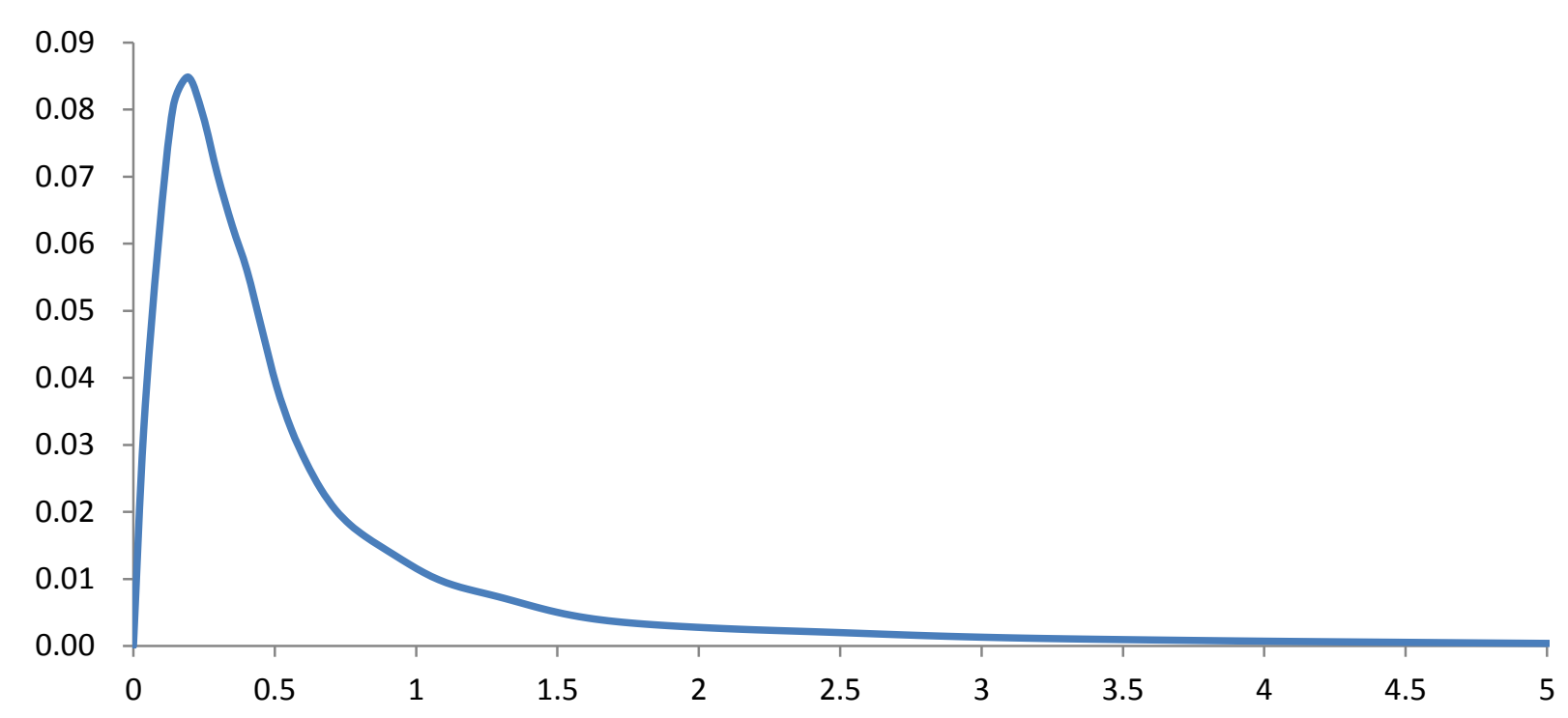

Figure 4 Ergodic distribution for relative SGRPPC of all counties and county-level cities with annual transitions, 1997-2010

Source: Authors' calculation. 


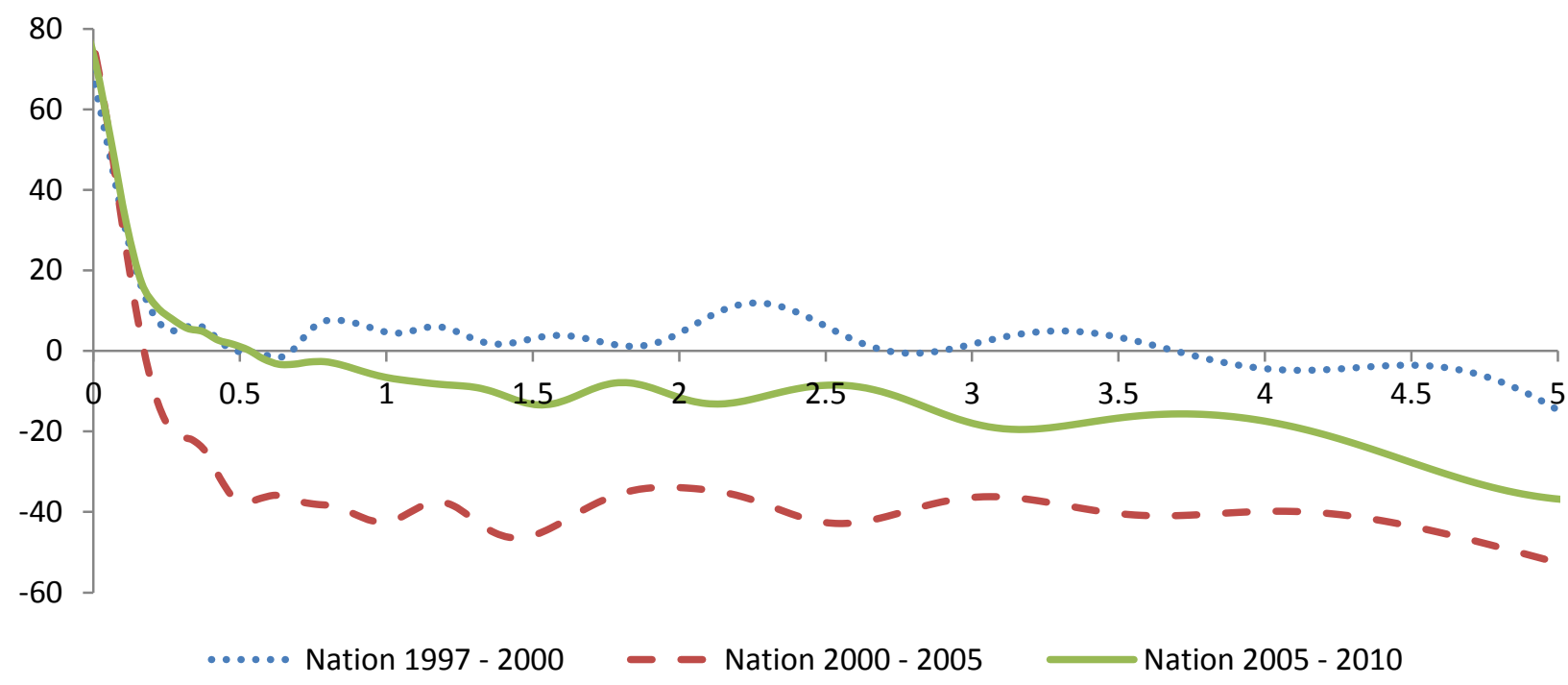

Figure 5 Mobility Probability Plot (MPP) for relative SGRPPC of all counties and county-level cities with different periods

Source: Authors' calculation.

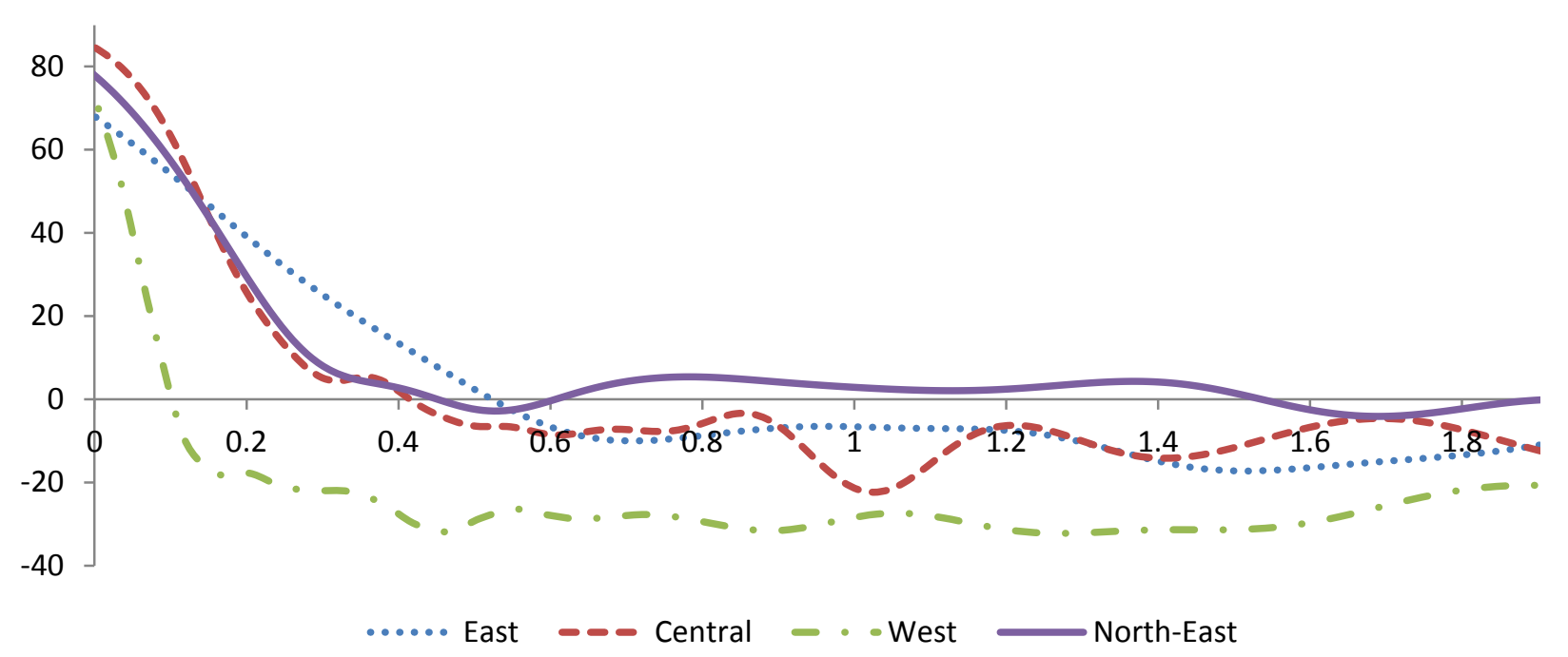

Figure 6 Mobility Probability Plot (MPP) for relative SGRPPC of all counties and county-level cities within different economic zones

Source: Authors' calculation. 
(a) Eastern

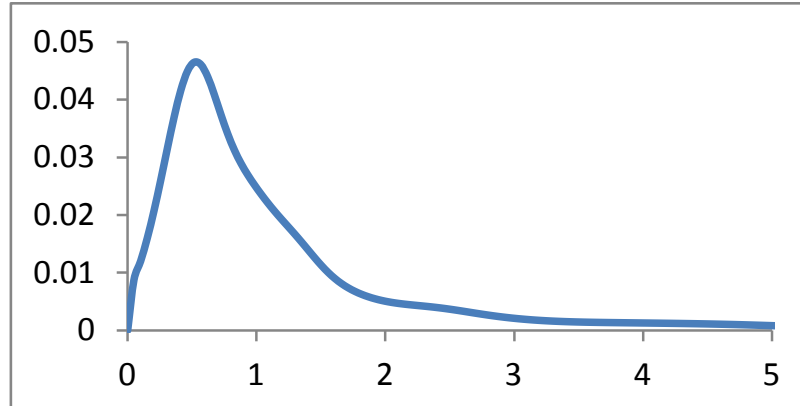

(c) Western

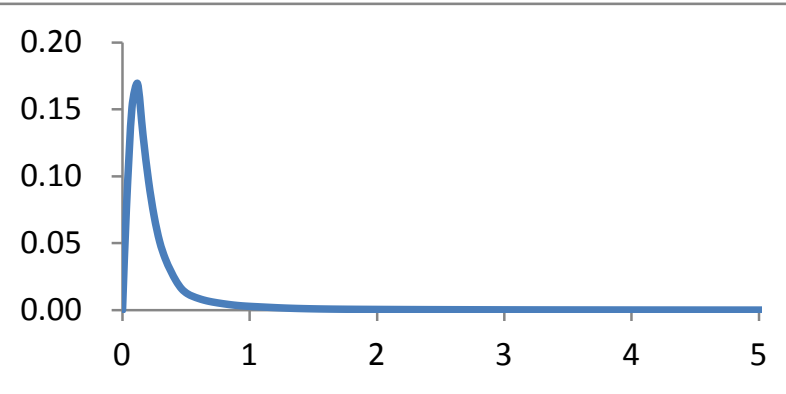

(b) Central

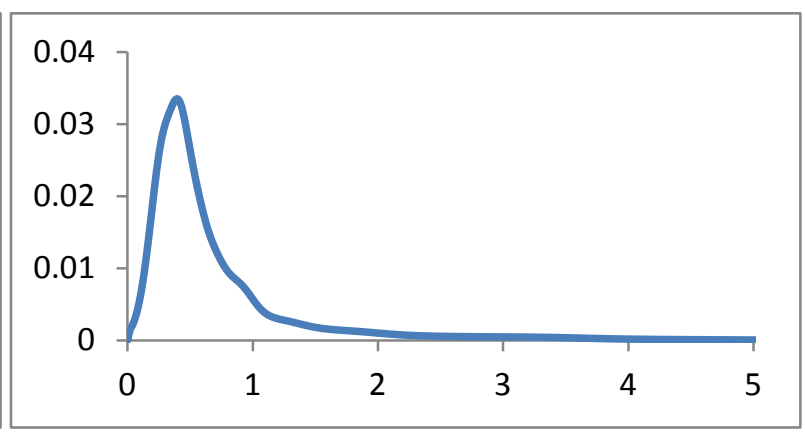

(d) North-Eastern

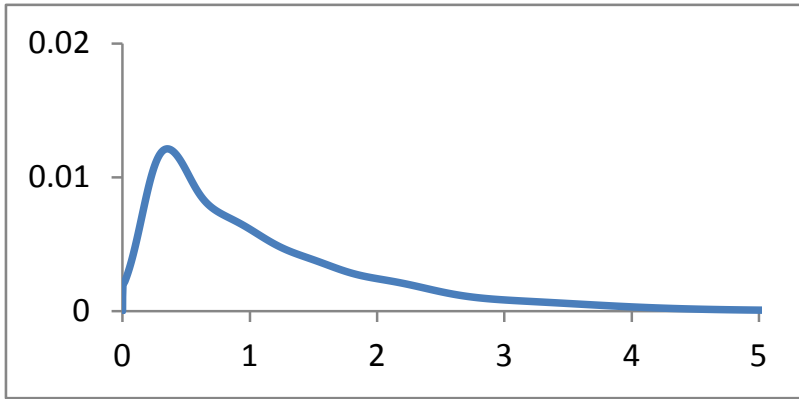

Figure 7 Ergodic distributions for relative SGRPPC of counties and county-level cities for each economic zone with annual transitions, 1997-2010

Source: Authors' calculation. 
(a) Eastern

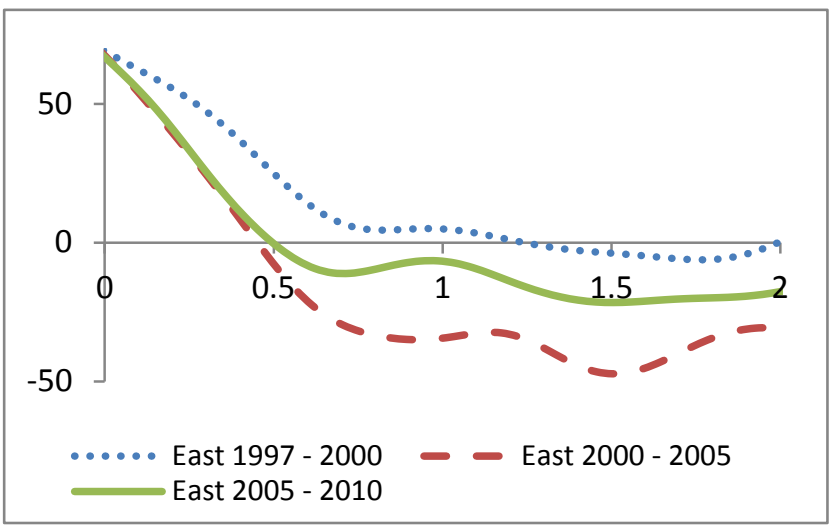

(c) Western

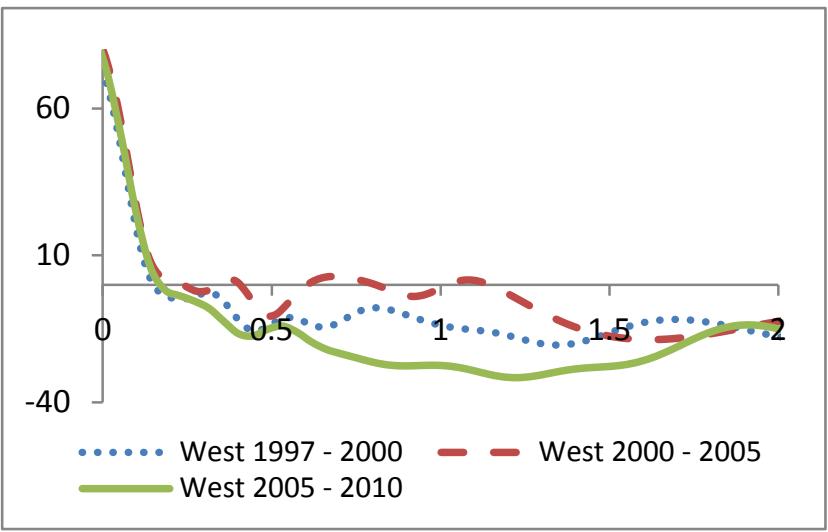

(b) Central

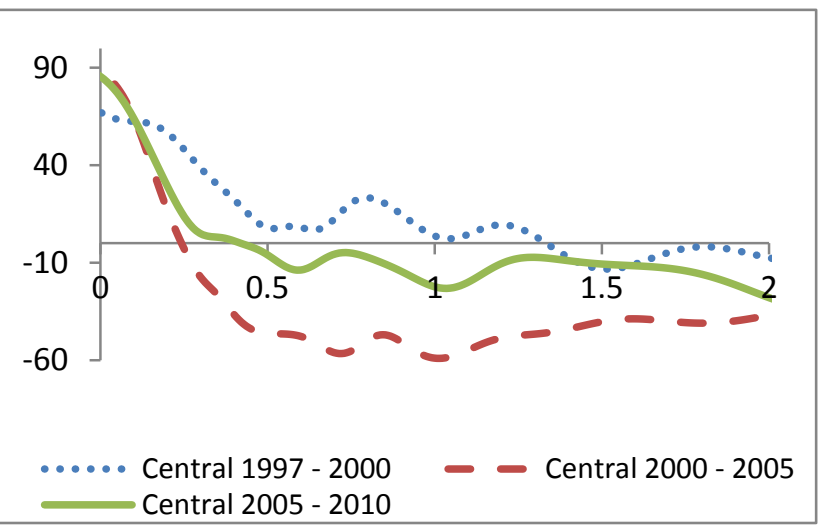

(d) North-Eastern

Figure 8 Mobility Probability Plot (MPP) for relative SGRPPC of all counties and county-level cities within different economic zones across different periods

Source: Authors' calculation. 
(a) Eastern

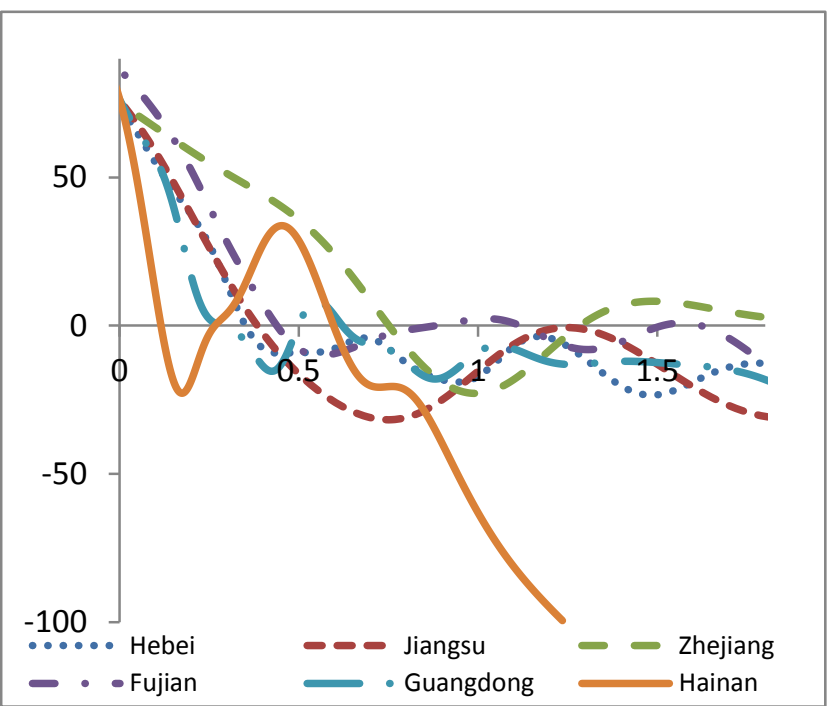

(c) Western

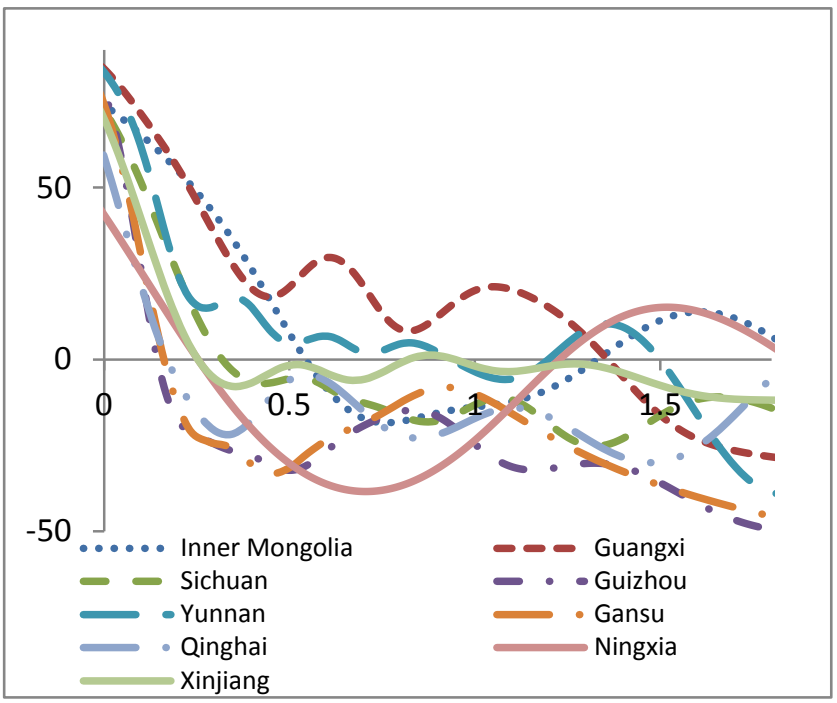

(b) Central

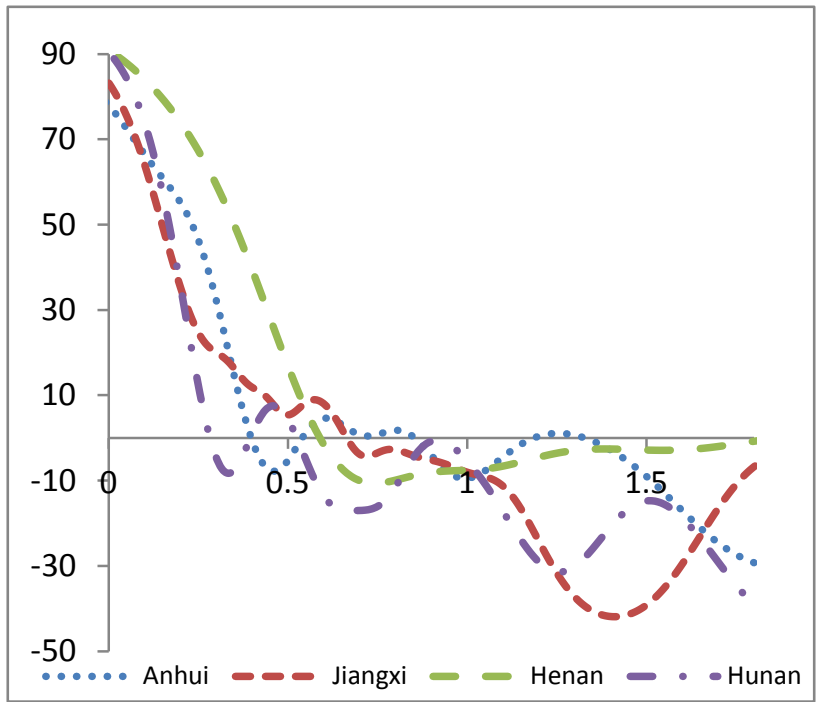

(d) North-Eastern

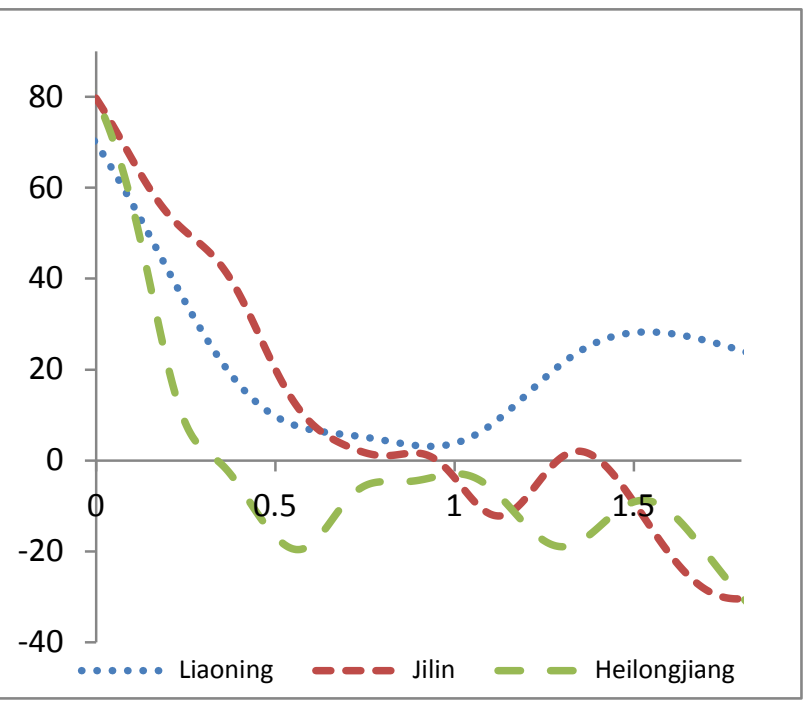

Figure 9 Mobility Probability Plot (MPP) for relative SGRPPC of all counties and county-level cities within different provinces

Source: Authors’ calculation. 

(a) Hebei
(b) Jiangsu
(c) Zhejiang
(d) Fujian
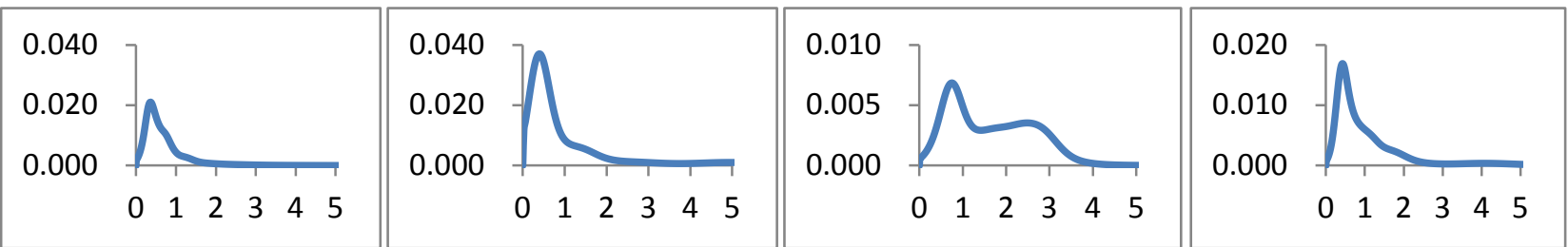

(e) Guangdong

(f) Hainan

(g) Anhui

(h) Jiangxi
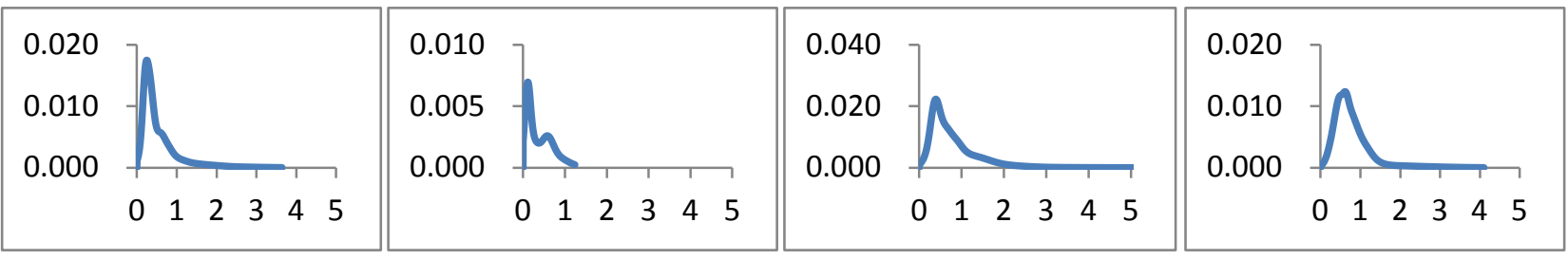

(i) Henan

(j) Hunan

(k) Inner Mongolia

(l) Guangxi
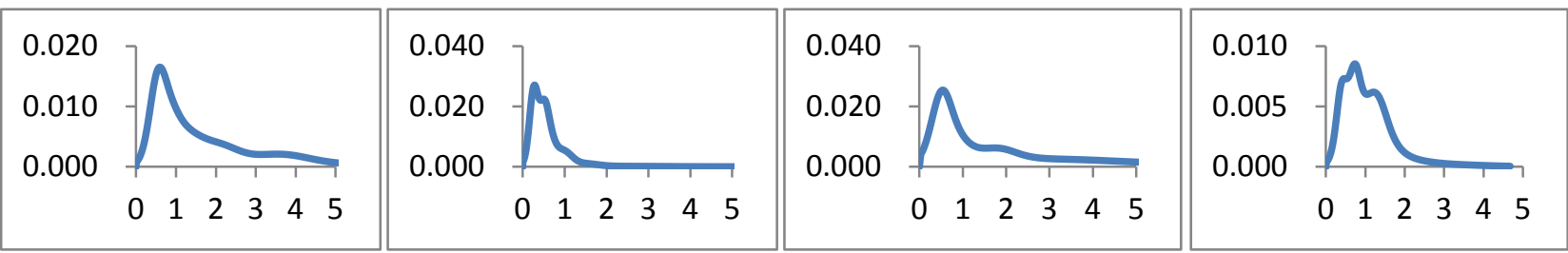

(m) Sichuan

(n) Guizhou

(o) Yunnan

(p) Gansu
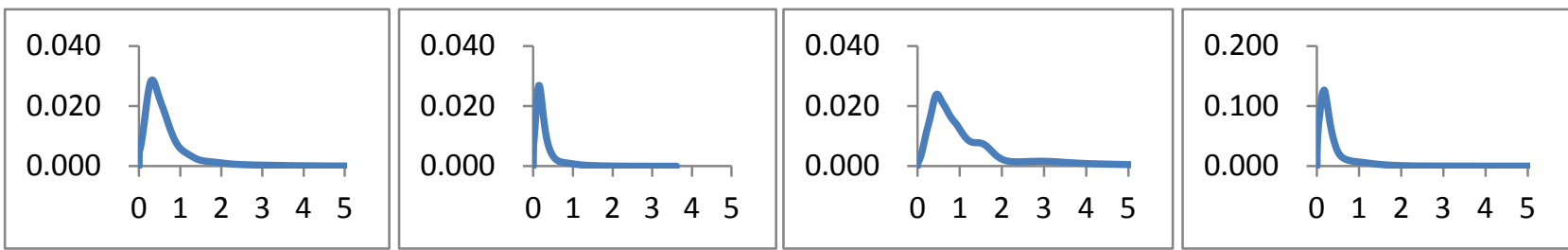

(q) Qinghai

(r) Ningxia

(s) Xinjiang

(t) Liaoning
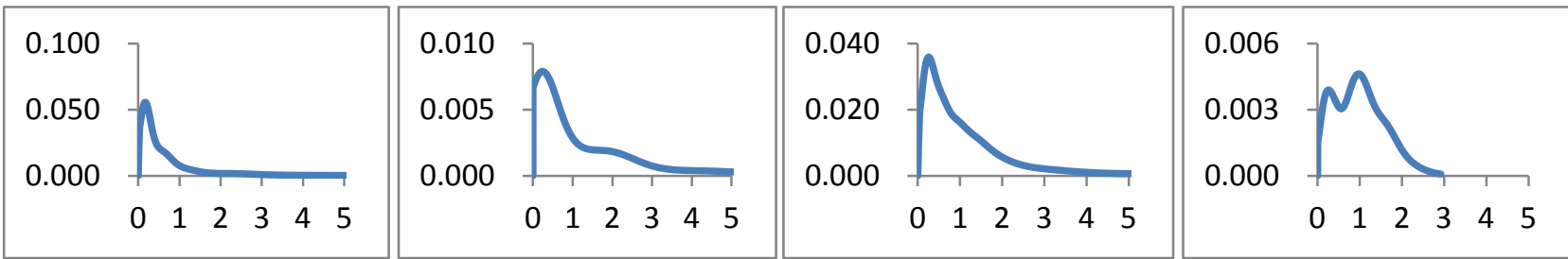

(u) Jilin

(v) Heilongjiang
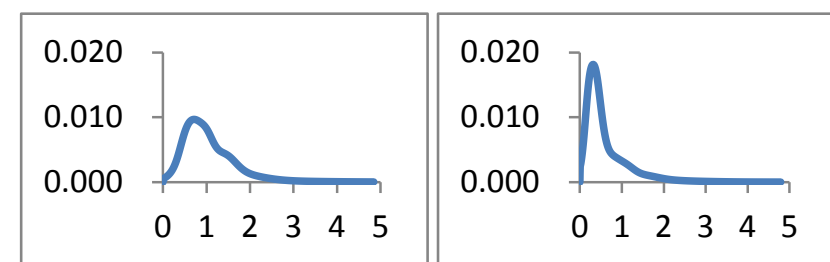

Figure 10 Ergodic distributions for relative SGRPPC of counties and county-level cities for each province with annual transitions, 1997-2010

Source: Authors' calculation. 


\section{Reference}

Akhmat, G., Bochun, Y., 2010. Rapidly Changing Dynamics of Urbanization in China; Escalating Regional Inequalities and Urban Management Problems. Journal of Sustainable Development 3, 153 - 158.

Alesina, A., Perotti, R., 1996. Income Distribution, Political Instability, and Investment. European Economic Review 40, 1203 - 1228.

Alesina, A., Rodrik, D., 1994. Distributive Politics and Economic Growth. Quarterly Journal of Economics 109, 465 - 490.

Barro, R.J., Sala-I-Martin, X., 1991. Convergence across States and Regions. Brookings Papers on Economic Activity 22, 107 - 182.

Barro, R.J., Sala-I-Martin, X., 1992. Convergence. Journal of Political Economy 100, 223 - 251.

Bernard, A.B., Durlauf, S.N., 1995. Convergence in International Output. Journal of Applied Econometrics 10, 97 - 108.

Bernard, A.B., Durlauf, S.N., 1996. Interpreting Tests of the Convergence Hypothesis. Journal of Econometrics 71, 161 - 173.

Cheng, J.Y.S., Zhang, M., 1998. An Analysis of Regional Differences in China and the Delayed Development of the Central and Western Regions. Issues and Studies 34, 35 - 68.

Cheong, T.S. 2012. Trends, Determinants and Consequences of Regional Inequality in China: New Evidence. University of Western Australia, Perth.

Cheong, T.S., Wu, Y., 2012. Regional Disparity, Transitional Dynamics and Convergence in China. University of Western Australia Business School Discussion Paper 12.23.

Cheong, T.S., Wu, Y., 2013a. Inequality and Crime Rates in China. University of Western Australia Business School Discussion Paper 13.11.

Cheong, T.S., Wu, Y., 2013b. Regional Disparity, Transitional Dynamics and Convergence in China. Journal of Asian Economics 29, 1 - 14.

Cheong, T.S., Wu, Y., 2014. The Impacts of Structural Transformation and Industrial Upgrading on Regional Inequality in China. University of Western Australia Business School Discussion Paper 14.09.

Cheshire, P., Magrini, S., 2000. Endogenous Processes in European Regional Growth: Convergence and Policy. Growth and Change 31, 455 - 479.

Deininger, K., Squire, L., 1998. New Ways of Looking at Old Issues: Inequality and Growth. Journal of Development Economics 57, 259 - 287.

Fan, C.C., 1995. Of Belts and Ladders: State Policy and Uneven Regional Development in Post-Mao China. Annals of the Association of American Geographers 85, 421 - 449.

Fan, C.C., 1997. Uneven Development and Beyond: Regional Development Theory in Post-Mao China. International Journal of Urban and Regional Research 21, 620 - 639.

Foster, J.E., Rothbaum, J., 2012. Mobility Curves: Using Cutoffs to Measure Absolute Mobility. Unpublished Manuscript.

Fosu, A.K., 2009. Inequality and the Impact of Growth on Poverty: Comparative Evidence for 
Sub-Saharan Africa. Journal of Development Studies 45, 726 - 745.

Golley, J., 2002. Regional Patterns of Industrial Development during China's Economic Transition.

Economics of Transition 10, 761 - 801.

Golley, J., 2007. China's Western Development Strategy and Nature versus Nurture. Journal of Chinese Economic and Business Studies 5, 115 - 129.

Goodman, D.S.G., 2004. The Campaign to "Open Up the West": National, Provincial-Level and Local Perspectives. The China Quarterly 178, 317 - 334.

He, C., Wei, Y.D., Xie, X., 2008. Globalization, Institutional Change, and Industrial Location:

Economic Transition and Industrial Concentration in China. Regional Studies 42, 923 - 945.

He, J., Zhang, X., 2007. Spatial-Temporal Analysis of China's Regional Income Distribution

Dynamics. South China Journal of Economics (in Chinese).

He, S.Q., 2010. Dynamics of Chinese Agricultural Trade Patterns Pre-and Post-WTO Periods. The Chinese Economy 43, 5 - 25.

Herrerías, M.J., 2012. Weighted Convergence and Regional Growth in China: an Alternative Approach (1952-2008). The Annals of Regional Science 49, 685 - 718.

Herrerías, M.J., Orts, V., Tortosa-Ausina, E., 2010. Weighted Convergence and Regional Clusters across China. Papers in Regional Science 90, 703 - 734.

Herrmann-Pillath, C., Kirchert, D., Pan, J., 2002a. Disparities in Chinese Economic Development: Approaches on Different Levels of Aggregation. Economic Systems 26, 31 - 54.

Herrmann-Pillath, C., Kirchert, D., Pan, J., 2002b. Prefecture-level Statistics as a Source of Data for Research into China's Regional Development. The China Quarterly, 956 - 985.

Herzfeld, T., 2008. Inter-Regional Output Distribution: A Comparison of Russian and Chinese Experience. Post-Communist Economies 20, 431 - 447.

Ho, C.-Y., Li, D., 2006. Spatial Analysis of City Income Distribution Dynamics in China, Unpublished manuscripts.

Ho, C.-Y., Li, D., 2010. Spatial Dependence and Divergence across Chinese Cities. Review of Development Economics 14, 386 - 403.

Hobijn, B., Franses, P.H., 2000. Asymptotically Perfect and Relative Convergence of Productivity. Journal of Applied Econometrics 15, 59 - 81.

Huang, H.-C., Lin, Y.-C., Yeh, C.-C., 2009. Joint Determinations of Inequality and Growth. Economics Letters 103, 163 - 166.

Huang, J.-T., Kuo, C.-C., Kao, A.-P., 2003. The Inequality of Regional Economic Development in China between 1991 and 2001. Journal of Chinese Economic and Business Studies 1, 273 285.

Hyndman, R.J., 1996. Computing and Graphing Highest Density Regions. The American Statistician 50, 120 - 126.

Hyndman, R.J., Bashtannyk, D.M., Grunwald, G.K., 1996. Estimating and Visualizing Conditional Densities. Journal of Computational and Graphical Statistics 5, 315 - 336.

Johnson, P.A., 2000. A Nonparametric Analysis of Income Convergence across the US States. Economics Letters 69, 219 - 223. 
Johnson, P.A., 2005. A Continuous State Space Approach to "Convergence by Parts". Economics Letters 86, 317 - 321.

Juessen, F., 2009. A Distribution Dynamics Approach to Regional GDP Convergence in Unified Germany. Empirical Economics 37, 627 - 652.

Kanbur, R., Zhang, X., 2005. Fifty Years of Regional Inequality in China: a Journey Through Central Planning, Reform, and Openness. Review of Development Economics 9, 87 - 106.

Klasen, S., 2009. Inequality in Emerging Countries: Trends, Interpretations, and Implications for Development and Poverty Reduction. Intereconomics 44, 360 - 363.

Kuznets, S., 1955. Economic Growth and Income Inequality. American Economic Review 45, 1 - 28. Lai, H., 2007. Developing Central China: A New Regional Programme. China: An International Journal 5, 109 - 128.

Li, H., 2003. Dynamics of Income Distribution across Chinese Provinces during 1978-98. Journal of Chinese Economic and Business Studies 1, 145 - 157.

Li, Y., Wei, Y.H.D., 2010. The Spatial-Temporal Hierarchy of Regional Inequality of China. Applied Geography 30, 303 - 316.

Liao, F.H.F., Wei, Y.D., 2012. Dynamics, Space, and Regional Inequality in Provincial China: A Case Study of Guangdong Province. Applied Geography 35, 71 - 83.

Lim, L.K., McAleer, M., 2004. Convergence and Catching Up in ASEAN: A Comparative Analysis. Applied Economics 36, 137 - 153.

Liu, Y., Zou, W., 2011. Rural-urban Migration and Dynamics of Income Distribution in China: A Non-parametric Approach. China \&World Economy 19, 37 - 55.

Marshall, A., 1920. Principles of Economics. Macmillan, London.

Oxley, L., Greasley, D., 1995. A Time-Series Perspective on Convergence: Australia, UK and USA since 1870. Economic Record 71, 259 - 270.

Persson, T., Tabellini, G., 1994. Is Inequality Harmful for Growth? American Economic Review 84, $600-621$.

Pesaran, M.H., 2007. A Pair-Wise Approach to Testing for Output and Growth Convergence. Journal of Econometrics 138, 312 - 355.

Pradhan, R.P., 2009. Causal Nexus between Globalization and Income Inequality: An Empirical Study in China. Banking and Finance Letters 1, 141 - 150.

Pu, Y., Ma, R., Ge, Y., Huang, X., 2005. Spatial-Temporal Dynamics of Regional Convergence at County Level in Jiangsu. Chinese Geographical Science 15.

Quah, D., 1993a. Empirical Cross-Section Dynamics in Economic Growth. European Economic Review 37, 426 - 434.

Quah, D., 1993b. Galton's Fallacy and Tests of the Convergence Hypothesis. Scandinavian Journal of Economics 95, 427 - 443.

Quah, D., 1996a. Empirics for Economic Growth and Convergence. European Economic Review 40, $1353-1375$.

Quah, D., 1996b. Regional Convergence Clusters across Europe. European Economic Review 40, 951 - 958. 
Quah, D., 1996c. Twin Peaks: Growth and Convergence in Models of Distribution Dynamics. The Economic Journal 106, 1045 - 1055.

Quah, D., 1997. Empirics for Growth and Distribution: Stratification, Polarization, and Convergence Clubs. Journal of Economic Growth 2, 27 - 59.

Quah, D., 2001. Searching for Prosperity: A Comment Carnegie-Rochester Conference Series on Public Policy 55, 305 - 319.

Redding, S.J., 2010. The Empirics of New Economic Geography. Journal of Regional Science 50, $297-311$.

Rozelle, S., 1994. Rural Industrialization and Increasing Inequality: Emerging Patterns in China's Reforming Economy. Journal of Comparative Economics 19, 362 - 391.

Rozelle, S., 1996. Stagnation Without Equity: Patterns of Growth and Inequality in China's Rural Economy. The China Journal 35, 63 - 92.

Rupasingha, A., Goetz, S.J., 2007. Social and Political Forces as Determinants of Poverty: A Spatial Analysis. The Journal of Socio-Economics 36, 650 - 671.

Sakamoto, H., Fan, J., 2010. Distribution Dynamics and Convergence among 75 Cities and Counties in Yangtze River Delta in China: 1990-2005. Review of Urban and Regional Development Studies 22, 39 - 54.

Sakamoto, H., Fan, J., 2013. Regional Income Disparity in China Using Value-Added Data: Decomposition and Distribution Dynamics. Review of Urban \& Regional Development Studies 25, 16 - 33.

Sakamoto, H., Islam, N., 2008. Convergence across Chinese Provinces: An analysis Using Markov Transition Matrix. China Economic Review 19, 66 - 79.

Silverman, B.W., 1986. Density Estimation for Statistics and Data Analysis. Chapman and Hall, New York.

State Statistical Bureau, 1998 - 2011a. Provincial Statistical Yearbook. China Statistics Press, Beijing.

State Statistical Bureau, 1998 - 2011b. Provincial Yearbook. China Statistics Press, Beijing.

State Statistical Bureau, 2004 - 2008. China Statistical Yearbook for Regional Economy. China Statistics Press, Beijing.

State Statistical Bureau, 2013. China Statistical Yearbook. China Statistics Press, Beijing.

Tang, Z., Lu, D., 1996. China's Region-Oriented Preferential Policies at the Crossroads. Asia-Pacific Development Journal 3, 105 - 124.

Tsui, K.-Y., 2007. Forces Shaping China's Interprovincial Inequality. Review of Income and Wealth $53,60-92$.

Tsui, K.Y., 1996. Economic Reform and Interprovincial Inequality in China. Journal of Development Economics 50, 353 - 368.

Villaverde, J., Maza, A., 2012. Chinese per Capita Income Distribution, 1992-2007: A Regional Perspective. Asian Economic Journal 26, 313 - 331.

Villaverde, J., Maza, A., Ramasamy, B., 2010. Provincial Disparities in Post-reform China. China and World Economy 18, 73 - 95. 
Wan, G., 2004. Accounting for Income Inequality in Rural China: A Regression-Based Approach. Journal of Comparative Economics 32, 348 - 363.

Wang, C., 2011. Sources of Energy Productivity Growth and Its Distribution Dynamics in China. Resource and Energy Economics 33, 279 - 292.

Wang, Z., Zhu, J., 2013. Evolution of China's City-Size Distribution: Empirical Evidence from 1949 to 2008. The Chinese Economy 46, 38 - 54.

Wei, Y., 1998. Regional Inequality of Industrial Output in China, 1952 to 1990. Geografiska Annaler. Series B, Human Geography 80, 1 - 15.

Wei, Y.D., 1999. Regional Inequality in China. Progress in Human Geography 23, 49 - 59.

Wei, Y.D., 2002. Multiscale and Multimechanisms of Regional Inequality in China: Implications for Regional Policy. Journal of Contemporary China 11, 109 - 124.

Wei, Y.D., Fan, C.C., 2000. Regional Inequality in China: A Case Study of Jiangsu Province. Professional Geographer 52, 455 - 469.

Wei, Y.D., Kim, S., 2002. Widening Inter-County Inequality in Jiangsu Province, China, 1950-95. The Journal of Development Studies 38, 142 - 164.

Wei, Y.D., Ye, X., 2004. Regional Inequality in China: A Case Study of Zhejiang Province. Tijdschrift voor Economische en Sociale Geografie 95, 44 - 60.

Wei, Y.H.D., Ye, X., 2009. Beyond Convergence: Space, Scale, and Regional Inequality in China. Tijdschrift voor Economische en Sociale Geografie 100, 59 - 80.

Yang, D.T., 2002. What Has Caused Regional Inequality in China? China Economic Review 13, 331 - 334.

Yao, S., 1997. Industrialization and Spatial Income Inequality in Rural China, 1986-92. Economics of Transition 5, 97 - 112.

Yu, D., Wei, Y.D., 2007. Spatial Data Analysis of Regional Development in Greater Beijing, China, in a GIS Environment. Papers in Regional Science 87, 97 - 117.

Yu, M., 2012. Industrial Structural Upgrading and Poverty Reduction in China, The Untold Story: Structural Change for Poverty Reduction: The Case of the BRICS. Peking University, Beijing. Zhang, P., 2008. Revitalizing Old Industrial Base of Northeast China: Process, Policy and Challenge. Chinese Geographical Science 18, 109 - 118.

Zhang, Z., 1999. Rural Industrialization in China: From Backyard Furnaces to Township and Village Enterprises. East Asia : An International Quarterly 17, 61 - 87.

Zhao, S.X., Gu, C., 1995. A Policy Review on Spatial Strategy of Regional Development in China: 1953 - 92. China Report 31, 385 - 409.

Zhou, H., Zou, W., 2010. Income Distribution Dynamics of Urban Residents: The case of China (1995-2004). Frontiers of Economics in China 5, 114 - 134.

Zhu, S., Lai, M., Fu, X., 2008. Spatial Characteristics and Dynamics of Provincial Total Factor Productivity in China. Journal of Chinese Economic and Business Studies 6, 197 - 217. Zhuang, J., 2008. Inclusive Growth toward a Harmonious Society in the People's Republic of China: Policy Implications. Asian Development Review 25, 22 - 33. 
Editor, UWA Economics Discussion Papers:

Ernst Juerg Weber

Business School - Economics

University of Western Australia

35 Sterling Hwy

Crawley WA 6009

Australia

Email: ecoadmin@biz.uwa.edu.au

The Economics Discussion Papers are available at:

1980 - 2002: http://ecompapers.biz.uwa.edu.au/paper/PDF\%20of\%20Discussion\%20Papers/

Since 2001: http://ideas.repec.org/s/uwa/wpaper1.html

Since 2004: $\quad$ http://www.business.uwa.edu.au/school/disciplines/economics

\begin{tabular}{|c|c|c|}
\hline \multicolumn{3}{|c|}{$\begin{array}{l}\text { ECONOMICS DISCUSSION PAPERS } \\
2012\end{array}$} \\
\hline $\begin{array}{l}\text { DP } \\
\text { NUMBER }\end{array}$ & AUTHORS & TITLE \\
\hline 12.01 & $\begin{array}{l}\text { Clements, K.W., Gao, G., and } \\
\text { Simpson, T. }\end{array}$ & $\begin{array}{l}\text { DISPARITIES IN INCOMES AND PRICES } \\
\text { INTERNATIONALLY }\end{array}$ \\
\hline 12.02 & Tyers, R. & $\begin{array}{l}\text { THE RISE AND ROBUSTNESS OF ECONOMIC FREEDOM } \\
\text { IN CHINA }\end{array}$ \\
\hline 12.03 & Golley, J. and Tyers, R. & $\begin{array}{l}\text { DEMOGRAPHIC DIVIDENDS, DEPENDENCIES AND } \\
\text { ECONOMIC GROWTH IN CHINA AND INDIA }\end{array}$ \\
\hline 12.04 & Tyers, R. & LOOKING INWARD FOR GROWTH \\
\hline 12.05 & Knight, K. and McLure, M. & THE ELUSIVE ARTHUR PIGOU \\
\hline 12.06 & McLure, M. & $\begin{array}{l}\text { ONE HUNDRED YEARS FROM TODAY: A. C. PIGOU'S } \\
\text { WEALTH AND WELFARE }\end{array}$ \\
\hline 12.07 & Khuu, A. and Weber, E.J. & HOW AUSTRALIAN FARMERS DEAL WITH RISK \\
\hline 12.08 & Chen, M. and Clements, K.W. & PATTERNS IN WORLD METALS PRICES \\
\hline 12.09 & Clements, K.W. & UWA ECONOMICS HONOURS \\
\hline 12.10 & Golley, J. and Tyers, R. & $\begin{array}{l}\text { CHINA'S GENDER IMBALANCE AND ITS ECONOMIC } \\
\text { PERFORMANCE }\end{array}$ \\
\hline 12.11 & Weber, E.J. & $\begin{array}{l}\text { AUSTRALIAN FISCAL POLICY IN THE AFTERMATH OF } \\
\text { THE GLOBAL FINANCIAL CRISIS }\end{array}$ \\
\hline 12.12 & Hartley, P.R. and Medlock III, K.B. & $\begin{array}{l}\text { CHANGES IN THE OPERATIONAL EFFICIENCY OF } \\
\text { NATIONAL OIL COMPANIES }\end{array}$ \\
\hline 12.13 & $\mathrm{Li}, \mathrm{L}$. & $\begin{array}{l}\text { HOW MUCH ARE RESOURCE PROJECTS WORTH? A } \\
\text { CAPITAL MARKET PERSPECTIVE }\end{array}$ \\
\hline 12.14 & Chen, A. and Groenewold, N. & $\begin{array}{l}\text { THE REGIONAL ECONOMIC EFFECTS OF A REDUCTION } \\
\text { IN CARBON EMISSIONS AND AN EVALUATION OF } \\
\text { OFFSETTING POLICIES IN CHINA }\end{array}$ \\
\hline 12.15 & Collins, J., Baer, B. and Weber, E.J. & $\begin{array}{l}\text { SEXUAL SELECTION, CONSPICUOUS CONSUMPTION } \\
\text { AND ECONOMIC GROWTH }\end{array}$ \\
\hline
\end{tabular}




\begin{tabular}{|c|c|c|}
\hline \multicolumn{3}{|c|}{$\begin{array}{l}\text { ECONOMICS DISCUSSION PAPERS } \\
2012\end{array}$} \\
\hline $\begin{array}{l}\text { DP } \\
\text { NUMBER }\end{array}$ & AUTHORS & TITLE \\
\hline 12.16 & $\mathrm{Wu}, \mathrm{Y}$. & TRENDS AND PROSPECTS IN CHINA'S R\&D SECTOR \\
\hline 12.17 & Cheong, T.S. and Wu, Y. & $\begin{array}{l}\text { INTRA-PROVINCIAL INEQUALITY IN CHINA: AN } \\
\text { ANALYSIS OF COUNTY-LEVEL DATA }\end{array}$ \\
\hline 12.18 & Cheong, T.S. & THE PATTERNS OF REGIONAL INEQUALITY IN CHINA \\
\hline 12.19 & Wu, Y. & $\begin{array}{l}\text { ELECTRICITY MARKET INTEGRATION: GLOBAL } \\
\text { TRENDS AND IMPLICATIONS FOR THE EAS REGION }\end{array}$ \\
\hline 12.20 & Knight, K. & $\begin{array}{l}\text { EXEGESIS OF DIGITAL TEXT FROM THE HISTORY OF } \\
\text { ECONOMIC THOUGHT: A COMPARATIVE } \\
\text { EXPLORATORY TEST }\end{array}$ \\
\hline 12.21 & Chatterjee, I. & $\begin{array}{l}\text { COSTLY REPORTING, EX-POST MONITORING, AND } \\
\text { COMMERCIAL PIRACY: A GAME THEORETIC } \\
\text { ANALYSIS }\end{array}$ \\
\hline 12.22 & Pen, S.E. & QUALITY-CONSTANT ILLICIT DRUG PRICES \\
\hline 12.23 & Cheong, T.S. and Wu, Y. & $\begin{array}{l}\text { REGIONAL DISPARITY, TRANSITIONAL DYNAMICS } \\
\text { AND CONVERGENCE IN CHINA }\end{array}$ \\
\hline 12.24 & Ezzati, P. & $\begin{array}{l}\text { FINANCIAL MARKETS INTEGRATION OF IRAN WITHIN } \\
\text { THE MIDDLE EAST AND WITH THE REST OF THE } \\
\text { WORLD }\end{array}$ \\
\hline 12.25 & Kwan, F., Wu, Y. and Zhuo, S. & $\begin{array}{l}\text { RE-EXAMINATION OF THE SURPLUS AGRICULTURAL } \\
\text { LABOUR IN CHINA }\end{array}$ \\
\hline 12.26 & $\mathrm{Wu}, \mathrm{Y}$. & R\&D BEHAVIOUR IN CHINESE FIRMS \\
\hline 12.27 & Tang, S.H.K. and Yung, L.C.W. & $\begin{array}{l}\text { MAIDS OR MENTORS? THE EFFECTS OF LIVE-IN } \\
\text { FOREIGN DOMESTIC WORKERS ON SCHOOL } \\
\text { CHILDREN'S EDUCATIONAL ACHIEVEMENT IN HONG } \\
\text { KONG }\end{array}$ \\
\hline 12.28 & Groenewold, N. & $\begin{array}{l}\text { AUSTRALIA AND THE GFC: SAVED BY ASTUTE FISCAL } \\
\text { POLICY? }\end{array}$ \\
\hline
\end{tabular}




\begin{tabular}{|c|c|c|}
\hline \multicolumn{3}{|c|}{$\begin{array}{l}\text { ECONOMICS DISCUSSION PAPERS } \\
2013\end{array}$} \\
\hline $\begin{array}{l}\text { DP } \\
\text { NUMBER }\end{array}$ & AUTHORS & TITLE \\
\hline 13.01 & $\begin{array}{l}\text { Chen, M., Clements, K.W. and } \\
\text { Gao, G. }\end{array}$ & THREE FACTS ABOUT WORLD METAL PRICES \\
\hline 13.02 & Collins, J. and Richards, O. & $\begin{array}{l}\text { EVOLUTION, FERTILITY AND THE AGEING } \\
\text { POPULATION }\end{array}$ \\
\hline 13.03 & $\begin{array}{l}\text { Clements, K., Genberg, H., Harberger, A., } \\
\text { Lothian, J.,Mundell, R., Sonnenschein, } \\
\text { H. and Tolley, G. }\end{array}$ & LARRY SJAASTAD, 1934-2012 \\
\hline 13.04 & Robitaille, M.C. and Chatterjee, I. & MOTHERS-IN-LAW AND SON PREFERENCE IN INDIA \\
\hline 13.05 & Clements, K.W. and Izan, I.H.Y. & $\begin{array}{l}\text { REPORT ON THE } 25^{\mathrm{TH}} \text { PHD CONFERENCE IN } \\
\text { ECONOMICS AND BUSINESS }\end{array}$ \\
\hline 13.06 & Walker, A. and Tyers, R. & $\begin{array}{l}\text { QUANTIFYING AUSTRALIA’S “THREE SPEED” } \\
\text { BOOM }\end{array}$ \\
\hline 13.07 & $\mathrm{Yu}, \mathrm{F}$. and $\mathrm{Wu}, \mathrm{Y}$. & $\begin{array}{l}\text { PATENT EXAMINATION AND DISGUISED } \\
\text { PROTECTION }\end{array}$ \\
\hline 13.08 & $\mathrm{Yu}, \mathrm{F}$. and $\mathrm{Wu}, \mathrm{Y}$. & $\begin{array}{l}\text { PATENT CITATIONS AND KNOWLEDGE } \\
\text { SPILLOVERS: AN ANALYSIS OF CHINESE PATENTS } \\
\text { REGISTER IN THE US }\end{array}$ \\
\hline 13.09 & Chatterjee, I. and Saha, B. & BARGAINING DELEGATION IN MONOPOLY \\
\hline 13.10 & Cheong, T.S. and Wu, Y. & $\begin{array}{l}\text { GLOBALIZATION AND REGIONAL INEQUALITY IN } \\
\text { CHINA }\end{array}$ \\
\hline 13.11 & Cheong, T.S. and Wu, Y. & INEQUALITY AND CRIME RATES IN CHINA \\
\hline 13.12 & Robertson, P.E. and Ye, L. & ON THE EXISTENCE OF A MIDDLE INCOME TRAP \\
\hline 13.13 & Robertson, P.E. & THE GLOBAL IMPACT OF CHINA’S GROWTH \\
\hline 13.14 & $\begin{array}{l}\text { Hanaki, N., Jacquemet, N., } \\
\text { Luchini, S., and Zylbersztejn, A. }\end{array}$ & $\begin{array}{l}\text { BOUNDED RATIONALITY AND STRATEGIC } \\
\text { UNCERTAINTY IN A SIMPLE DOMINANCE } \\
\text { SOLVABLE GAME }\end{array}$ \\
\hline 13.15 & $\begin{array}{l}\text { Okatch, Z., Siddique, A. and Rammohan, } \\
\text { A. }\end{array}$ & $\begin{array}{l}\text { DETERMINANTS OF INCOME INEQUALITY IN } \\
\text { BOTSWANA }\end{array}$ \\
\hline 13.16 & Clements, K.W. and Gao, G. & $\begin{array}{l}\text { A MULTI-MARKET APPROACH TO MEASURING THE } \\
\text { CYCLE }\end{array}$ \\
\hline 13.17 & Chatterjee, I. and Ray, R. & $\begin{array}{l}\text { THE ROLE OF INSTITUTIONS IN THE INCIDENCE OF } \\
\text { CRIME AND CORRUPTION }\end{array}$ \\
\hline 13.18 & Fu, D. and Wu, Y. & $\begin{array}{l}\text { EXPORT SURVIVAL PATTERN AND DETERMINANTS } \\
\text { OF CHINESE MANUFACTURING FIRMS }\end{array}$ \\
\hline 13.19 & Shi, X., Wu, Y. and Zhao, D. & $\begin{array}{l}\text { KNOWLEDGE INTENSIVE BUSINESS SERVICES AND } \\
\text { THEIR IMPACT ON INNOVATION IN CHINA }\end{array}$ \\
\hline 13.20 & $\begin{array}{l}\text { Tyers, R., Zhang, Y. and } \\
\text { Cheong, T.S. }\end{array}$ & $\begin{array}{l}\text { CHINA'S SAVING AND GLOBAL ECONOMIC } \\
\text { PERFORMANCE }\end{array}$ \\
\hline 13.21 & Collins, J., Baer, B. and Weber, E.J. & $\begin{array}{l}\text { POPULATION, TECHNOLOGICAL PROGRESS AND } \\
\text { THE EVOLUTION OF INNOVATIVE POTENTIAL }\end{array}$ \\
\hline
\end{tabular}




\begin{tabular}{|c|c|c|}
\hline \multicolumn{3}{|c|}{$\begin{array}{l}\text { ECONOMICS DISCUSSION PAPERS } \\
2013\end{array}$} \\
\hline $\begin{array}{l}\text { DP } \\
\text { NUMBER }\end{array}$ & AUTHORS & TITLE \\
\hline 13.22 & Hartley, P.R. & THE FUTURE OF LONG-TERM LNG CONTRACTS \\
\hline 13.23 & Tyers, R. & $\begin{array}{l}\text { A SIMPLE MODEL TO STUDY GLOBAL } \\
\text { MACROECONOMIC INTERDEPENDENCE }\end{array}$ \\
\hline 13.24 & McLure, M. & $\begin{array}{l}\text { REFLECTIONS ON THE QUANTITY THEORY: PIGOU IN } \\
1917 \text { AND PARETO IN 1920-21 }\end{array}$ \\
\hline 13.25 & Chen, A. and Groenewold, N. & $\begin{array}{l}\text { REGIONAL EFFECTS OF AN EMISSIONS-REDUCTION } \\
\text { POLICY IN CHINA: THE IMPORTANCE OF THE } \\
\text { GOVERNMENT FINANCING METHOD }\end{array}$ \\
\hline 13.26 & Siddique, M.A.B. & $\begin{array}{l}\text { TRADE RELATIONS BETWEEN AUSTRALIA AND } \\
\text { THAILAND: } 1990 \text { TO } 2011\end{array}$ \\
\hline 13.27 & Li, B. and Zhang, J. & $\begin{array}{l}\text { GOVERNMENT DEBT IN AN INTERGENERATIONAL } \\
\text { MODEL OF ECONOMIC GROWTH, ENDOGENOUS } \\
\text { FERTILITY, AND ELASTIC LABOR WITH AN } \\
\text { APPLICATION TO JAPAN }\end{array}$ \\
\hline 13.28 & Robitaille, M. and Chatterjee, I. & $\begin{array}{l}\text { SEX-SELECTIVE ABORTIONS AND INFANT } \\
\text { MORTALITY IN INDIA: THE ROLE OF PARENTS' } \\
\text { STATED SON PREFERENCE }\end{array}$ \\
\hline 13.29 & Ezzati, P. & $\begin{array}{l}\text { ANALYSIS OF VOLATILITY SPILLOVER EFFECTS: } \\
\text { TWO-STAGE PROCEDURE BASED ON A MODIFIED } \\
\text { GARCH-M }\end{array}$ \\
\hline 13.30 & Robertson, P. E. & $\begin{array}{l}\text { DOES A FREE MARKET ECONOMY MAKE AUSTRALIA } \\
\text { MORE OR LESS SECURE IN A GLOBALISED WORLD? }\end{array}$ \\
\hline 13.31 & $\begin{array}{l}\text { Das, S., Ghate, C. and } \\
\text { Robertson, P. E. }\end{array}$ & $\begin{array}{l}\text { REMOTENESS AND UNBALANCED GROWTH: } \\
\text { UNDERSTANDING DIVERGENCE ACROSS INDIAN } \\
\text { DISTRICTS }\end{array}$ \\
\hline 13.32 & Robertson, P.E. and Sin, A. & $\begin{array}{l}\text { MEASURING HARD POWER: CHINA’S ECONOMIC } \\
\text { GROWTH AND MILITARY CAPACITY }\end{array}$ \\
\hline 13.33 & Wu, Y. & $\begin{array}{l}\text { TRENDS AND PROSPECTS FOR THE RENEWABLE } \\
\text { ENERGY SECTOR IN THE EAS REGION }\end{array}$ \\
\hline 13.34 & $\begin{array}{l}\text { Yang, S., Zhao, D., Wu, Y. and } \\
\text { Fan, J. }\end{array}$ & $\begin{array}{l}\text { REGIONAL VARIATION IN CARBON EMISSION AND ITS } \\
\text { DRIVING FORCES IN CHINA: AN INDEX } \\
\text { DECOMPOSITION ANALYSIS }\end{array}$ \\
\hline
\end{tabular}




\begin{tabular}{|c|c|c|}
\hline \multicolumn{3}{|c|}{$\begin{array}{c}\text { ECONOMICS DISCUSSION PAPERS } \\
2014\end{array}$} \\
\hline $\begin{array}{l}\text { DP } \\
\text { NUMBER }\end{array}$ & AUTHORS & TITLE \\
\hline 14.01 & $\begin{array}{l}\text { Boediono, Vice President of the } \\
\text { Republic of Indonesia }\end{array}$ & $\begin{array}{l}\text { THE CHALLENGES OF POLICY MAKING IN A YOUNG } \\
\text { DEMOCRACY: THE CASE OF INDONESIA (52ND } \\
\text { SHANN MEMORIAL LECTURE, 2013) }\end{array}$ \\
\hline 14.02 & Metaxas, P.E. and Weber, E.J. & $\begin{array}{l}\text { AN AUSTRALIAN CONTRIBUTION TO } \\
\text { INTERNATIONAL TRADE THEORY: THE DEPENDENT } \\
\text { ECONOMY MODEL }\end{array}$ \\
\hline 14.03 & Fan, J., Zhao, D., Wu, Y. and Wei, J. & $\begin{array}{l}\text { CARBON PRICING AND ELECTRICITY MARKET } \\
\text { REFORMS IN CHINA }\end{array}$ \\
\hline 14.04 & McLure, M. & $\begin{array}{l}\text { A.C. PIGOU'S MEMBERSHIP OF THE } \\
\text { 'CHAMBERLAIN-BRADBURY’ COMMITTEE. } \\
\text { PART I: THE HISTORICAL CONTEXT }\end{array}$ \\
\hline 14.05 & McLure, M. & $\begin{array}{l}\text { A.C. PIGOU'S MEMBERSHIP OF THE } \\
\text { 'CHAMBERLAIN-BRADBURY’ COMMITTEE. } \\
\text { PART II: ‘TRANSITIONAL’ AND ‘ONGOING’ ISSUES }\end{array}$ \\
\hline 14.06 & King, J.E. and McLure, M. & HISTORY OF THE CONCEPT OF VALUE \\
\hline 14.07 & Williams, A. & $\begin{array}{l}\text { A GLOBAL INDEX OF INFORMATION AND POLITICAL } \\
\text { TRANSPARENCY }\end{array}$ \\
\hline 14.08 & Knight, K. & $\begin{array}{l}\text { A.C. PIGOU'S THE THEORY OF UNEMPLOYMENT AND } \\
\text { ITS CORRIGENDA: THE LETTERS OF MAURICE } \\
\text { ALLEN, ARTHUR L. BOWLEY, RICHARD KAHN AND } \\
\text { DENNIS ROBERTSON }\end{array}$ \\
\hline 14.09 & Cheong, T.S. and Wu, Y. & $\begin{array}{l}\text { THE IMPACTS OF STRUCTURAL RANSFORMATION } \\
\text { AND INDUSTRIAL UPGRADING ON REGIONAL } \\
\text { INEQUALITY IN CHINA }\end{array}$ \\
\hline 14.10 & $\begin{array}{l}\text { Chowdhury, M.H., Dewan, M.N.A., } \\
\text { Quaddus, M., Naude, M. and } \\
\text { Siddique, A. }\end{array}$ & $\begin{array}{l}\text { GENDER EQUALITY AND SUSTAINABLE } \\
\text { DEVELOPMENT WITH A FOCUS ON THE COASTAL } \\
\text { FISHING COMMUNITY OF BANGLADESH }\end{array}$ \\
\hline 14.11 & Bon, J. & $\begin{array}{l}\text { UWA DISCUSSION PAPERS IN ECONOMICS: THE } \\
\text { FIRST } 750\end{array}$ \\
\hline 14.12 & Finlay, K. and Magnusson, L.M. & $\begin{array}{l}\text { BOOTSTRAP METHODS FOR INFERENCE WITH } \\
\text { CLUSTER-SAMPLE IV MODELS }\end{array}$ \\
\hline 14.13 & Chen, A. and Groenewold, N. & $\begin{array}{l}\text { THE EFFECTS OF MACROECONOMIC SHOCKS ON THE } \\
\text { DISTRIBUTION OF PROVINCIAL OUTPUT IN CHINA: } \\
\text { ESTIMATES FROM A RESTRICTED VAR MODEL }\end{array}$ \\
\hline 14.14 & Hartley, P.R. and Medlock III, K.B. & $\begin{array}{l}\text { THE VALLEY OF DEATH FOR NEW ENERGY } \\
\text { TECHNOLOGIES }\end{array}$ \\
\hline 14.15 & $\begin{array}{l}\text { Hartley, P.R., Medlock III, K.B., } \\
\text { Temzelides, T. and Zhang, X. }\end{array}$ & $\begin{array}{l}\text { LOCAL EMPLOYMENT IMPACT FROM COMPETING } \\
\text { ENERGY SOURCES: SHALE GAS VERSUS WIND } \\
\text { GENERATION IN TEXAS }\end{array}$ \\
\hline 14.16 & Tyers, R. and Zhang, Y. & $\begin{array}{l}\text { SHORT RUN EFFECTS OF THE ECONOMIC REFORM } \\
\text { AGENDA }\end{array}$ \\
\hline 14.17 & Clements, K.W., Si, J. and Simpson, T. & UNDERSTANDING NEW RESOURCE PROJECTS \\
\hline
\end{tabular}




\begin{tabular}{|c|c|c|}
\hline \multicolumn{3}{|c|}{$\begin{array}{c}\text { ECONOMICS DISCUSSION PAPERS } \\
2014\end{array}$} \\
\hline $\begin{array}{l}\text { DP } \\
\text { NUMBER }\end{array}$ & AUTHORS & TITLE \\
\hline 14.18 & Tyers, R. & $\begin{array}{l}\text { SERVICE OLIGOPOLIES AND AUSTRALIA'S } \\
\text { ECONOMY-WIDE PERFORMANCE }\end{array}$ \\
\hline 14.19 & Tyers, R. and Zhang, Y. & $\begin{array}{l}\text { REAL EXCHANGE RATE DETERMINATION AND } \\
\text { THE CHINA PUZZLE }\end{array}$ \\
\hline 14.20 & Ingram, S.R. & $\begin{array}{l}\text { COMMODITY PRICE CHANGES ARE } \\
\text { CONCENTRATED AT THE END OF THE CYCLE }\end{array}$ \\
\hline 14.21 & Cheong, T.S. and Wu, Y. & $\begin{array}{l}\text { CHINA'S INDUSTRIAL OUTPUT: A COUNTY-LEVEL } \\
\text { STUDY USING A NEW FRAMEWORK OF } \\
\text { DISTRIBUTION DYNAMICS ANALYSIS }\end{array}$ \\
\hline 14.22 & $\begin{array}{l}\text { Siddique, M.A.B., Wibowo, H. and } \\
\text { Wu, Y. }\end{array}$ & $\begin{array}{l}\text { FISCAL DECENTRALISATION AND INEQUALITY IN } \\
\text { INDONESIA: 1999-2008 }\end{array}$ \\
\hline 14.23 & Tyers, R. & $\begin{array}{l}\text { ASYMMETRY IN BOOM-BUST SHOCKS: } \\
\text { AUSTRALIAN PERFORMANCE WITH OLIGOPOLY }\end{array}$ \\
\hline 14.24 & Arora, V., Tyers, R. and Zhang, Y. & $\begin{array}{l}\text { RECONSTRUCTING THE SAVINGS GLUT: THE } \\
\text { GLOBAL IMPLICATIONS OF ASIAN EXCESS } \\
\text { SAVING }\end{array}$ \\
\hline 14.25 & Tyers, R. & $\begin{array}{l}\text { INTERNATIONAL EFFECTS OF CHINA'S RISE AND } \\
\text { TRANSITION: NEOCLASSICAL AND KEYNESIAN } \\
\text { PERSPECTIVES }\end{array}$ \\
\hline 14.26 & Milton, S. and Siddique, M.A.B. & $\begin{array}{l}\text { TRADE CREATION AND DIVERSION UNDER THE } \\
\text { THAILAND-AUSTRALIA FREE TRADE AGREEMENT } \\
\text { (TAFTA) }\end{array}$ \\
\hline 14.27 & Clements, K.W. and Li, L. & VALUING RESOURCE INVESTMENTS \\
\hline
\end{tabular}

